\title{
Dimensions and architecture of late Pleistocene submarine lobes off the northern margin of East Corsica
}

\author{
Deptuck M. E. ${ }^{1,{ }^{*}}$, Piper D. J. W. ${ }^{1}$, Savoye B. ${ }^{2}$, Gervais A. ${ }^{3}$ \\ ${ }^{1}$ Geological Survey of Canada (Atlantic), Dartmouth, NS, Canada \\ ${ }^{2}$ IFREMER, Laboratoire Environnements Sédimentaires, BP70, 29280 Plouzané, France \\ ${ }^{3}$ Université Bordeaux 1, Département de Géologie et Océanographie, Talence, France \\ *: Corresponding author : M. Deptuck, email address : mdeptuck@cnsopb.ns.ca
}

\begin{abstract}
:
Sandy lobe deposits on submarine fans are sensitive recorders of the types of sediment gravity flows supplied to a basin and are economically important as hydrocarbon reservoirs. This study investigates the causes of variability in 20 lobes in small late Pleistocene submarine fans off East Corsica. These lobes were imaged using ultra-high resolution boomer seismic profiles ( $<1 \mathrm{~m}$ vertical resolution) and sediment type was ground truthed using piston cores published in previous studies. Repeated crossings of the same depositional bodies were used to measure spatial changes in their dimensions and architecture. Most lobes increase abruptly down-slope to a peak thickness of 8 to $42 \mathrm{~m}$, beyond which they show a progressive, typically more gradual, decrease in thickness until they thin to below seismic resolution or pass into draping facies of the basin plain. Lobe areas range from 3 to $70 \mathrm{~km}^{2}$ and total lengths from 2 to $14 \mathrm{~km}$, with the locus of maximum sediment accumulation from 3 to $28 \mathrm{~km}$ from the shelf-break. Based on their location, dimensions, internal architecture and nature of the feeder channel, the lobes are divided into two end-member types. The first are small depositional bodies located in proximal settings, clustered near the toe-of-slope and fed by slope gullies or erosive channels lacking or with poorly developed levées (referred to as 'proximal isolated lobes'). The second are larger architecturally more complex depositional bodies deposited in more distal settings, outboard more stable and longer-lived levéed fan valleys (referred to as 'composite mid-fan lobes'). Hybrid lobe types are also observed. At least three hierarchical levels of compensation stacking are recognized. Individual beds and bed-sets stack to form lobe-elements; lobe-elements stack to form composite lobes; and composite lobes stack to form lobe complexes. Differences in the size, shape and architectural complexity of lobe deposits reflect several inter-related factors including: (i) flow properties (volume, duration, grain-size, concentration and velocity); (ii) the number and frequency of flows, and their degree of variation through time; (iii) gradient change and sea floor morphology at the mouth of the feeder conduit; (iv) lobe lifespan prior to avulsion or abandonment; and (v) feeder channel geometry and stability. In general, lobes outboard stable fan valleys that are connected to shelf-incised canyons are wider, longer and thicker, accumulate in more basinal locations and are architecturally more complex.
\end{abstract}

Keywords: Architecture, compensation stacking, dimensions, pleistocene, submarine lobes, turbidites 


\section{Introduction}

In submarine fans, sandy depositional bodies commonly accumulate in relatively unconfined settings at the termination of a range of submarine feeder conduits (from short-lived gullies to long-lived leveed fan valleys). They normally form convex-upward lens-shaped (cross-section) and lobate (plan view) deposits that we refer to generically as 'lobes' (see Shanmugam \& Moiola, 1991). This morphological usage includes a zone of potential channelling, scouring, and general amalgamation in the proximal parts of lobes (channel-lobe transition of Mutti \& Normark, 1987, 1991), and hence the mapped lobe bodies in this study are similar to 'suprafan' lobes of Normark (1978). Lobes may be single storey deposits (referred to as 'lobe-elements' in this study) or multistorey deposits comprised of several stacked lobe-elements that form a contiguous depositional body (referred to as 'composite lobes' in this study, discussed later). In ancient outcrops and on the modern seafloor, lobes show considerable architectural variability that may provide information about the properties of turbidity currents that built them and their sediment source characteristics (Normark \& Piper, 1991). In addition to providing a record of flows exiting channel confinement, lobes are economically important because of their potential as hydrocarbon reservoirs (Piper \& Normark, 2001). Variation in lateral continuity and vertical connectivity of lobe sand bodies impacts reservoir complexity and has a direct bearing on the number of wells required to produce a field.

Outcrop studies provide the most detailed observations of lobes, which are commonly described as sand-prone deposits consisting of generally tabular, non-channelled bodies 3 to $15 \mathrm{~m}$ thick (Mutti \& Normark, 1987). However, the paleogeographic location of many outcrops relative to the larger-scale ancient fan system is commonly uncertain, and changes in deposit character away from the outcrop face are generally poorly constrained. Flume-tank experiments also provide valuable insight into the flows that build lobes, but may suffer from scaling issues and need to be validated by natural systems (e.g. Parsons et al., 2002; Kubo, 2004; Al Ja'aidi et al., 2004; Baas et al., 2004). Defining modern lobes on $3.5-4.0 \mathrm{kHz}$ profiles has traditionally been difficult due to the lack of acoustic penetration and poor piston core penetration in sand-prone deposits (e.g. Navy fan - Normark et al., 1979; Piper \& Normark, 1983). Conventional subsurface studies using industry standard multichannel reflection seismic profiles on the other hand provide abundant acoustic penetration but at the expense of resolution. Lobe deposits commonly appear as singlecycle seismic reflections (e.g. Fonnesu, 2003; Adeogba et al., 2005), or as is the case in the North Sea (e.g. Sarg \& Skjold, 1982) and Jeanne d'Arc Basin (Deptuck, 2003), sub-circular to elongated 'mounds' of sand-prone deposits up to $60 \mathrm{~m}$ thick. Such data provide little information about the finer-scale architecture of lobe-like depositional bodies.

These various scales of observation can be linked by using ultra-high resolution seismic-reflection profiling, capable of resolving individual sand beds, ground truthed by piston cores. This approach was used by Piper et al. (1999) to study small sand-prone modern submarine fans off southern California. Such data-sets provide detailed information about the dimensions and distribution of lobes in submarine fans, with precise understanding of paleogeography (e.g. water depths, gradients, distance from the shelf-break, etc.) and potentially some controls on the initiation and character of the turbidity currents that deposited the lobes. They thus help bridge the resolution gap between outcrop studies and conventional subsurface studies, and may help to evaluate results from recent flume tank experiments.

The purpose of this paper is to describe, both qualitatively and quantitatively, the architecture of sandy lobes in small submarine fans off East Corsica. Our primary focus is on lobes deposited in the upper $75 \mathrm{~m}$ below the seafloor. Detailed measurements from ultra-high resolution reflectionseismic profiles provide insight into the distribution and dimensions of lobes off East Corsica. We use this information, combined with piston cores, to explore the depositional hierarchy within lobe bodies and to better understand the factors that control differences in lobe architecture. 


\section{Study area and stratigraphic context}

The island of Corsica (Fig. 1) is rugged and mountainous and has a maximum topographic relief of $2700 \mathrm{~m}$. Its eastern side is drained by several small, high-gradient rivers that transport coarse sand to fine silt and clay to a narrow continental shelf (5 to $25 \mathrm{~km}$ wide), with a shelf-break located at about the $110 \mathrm{~m}$ isobath (Stanley et al., 1980; Bellaiche et al., 1994). East of the shelfbreak, a narrow slope with an average gradient of $2-3^{\circ}$ defines the western margin of a relatively shallow $(<900 \mathrm{~m})$ and narrow $(<50 \mathrm{~km})$ fault-bounded depression known as the Corsican Trough (Stanley et al., 1980). The trough is approximately $150 \mathrm{~km}$ long, deepening and widening to the south. It is deepest in a ponded depression known as the Golo Basin, defined approximately by the $850 \mathrm{~m}$ isobath. The eastern side of the Corsican Trough is steep ( 3.5 to $\left.7.5^{\circ}\right)$ but the absence of canyons suggests that most of the recent sediment was derived from the island of Corsica and not across the Tuscany shelf. Periodic failures of the eastern slope, however, shed some sediment into the Corsican Trough (Gervais, 2002).

Three fan systems were identified by Bellaiche et al. (1994) along the eastern margin of Corsica, named from north to south the Golo, Tavignavo, and Fiume Orbo fan systems. The study area covers the outer shelf, slope and basin floor of the Golo fan system, which is comprised of several interfingering submarine fans supplied by a number of conduits ranging from large shelfindenting canyons to smaller erosive gullies (Fig. 1a) (e.g. Pichevin, 2000; Gervais, 2002; Deptuck, 2003; Pichevin et al., 2003, Gervais et al., 2004). Though several small rivers supplied the margin, the Golo River was the most important source of Pleistocene-Holocene terrigenous sediment (Bellaiche et al., 1994). The increased shelf width outboard the Golo River reflects the increased sediment supply to the shelf in this area. Regional stratigraphy and chronology are based principally on sparker reflection profiles and radiocarbon dating of core sediments presented by Gervais et al. $(2004,2006)$. Their regional reflectors I to J date approximately from the last fall in sea level, reflectors $\mathrm{J}$ to $\mathrm{K}$ from the last glacial maximum, and reflectors $\mathrm{K}$ to $\mathrm{L}$ from the subsequent rise in sea level to the end of the Younger Dryas. All of the lobes identified in this study post-date reflector I and were thus deposited under conditions of falling then rising to stable sea level.

\section{Data set and approach}

About 1300 line kilometres of Huntec DTS (deep-towed seismic) boomer profiles were collected in water depths of less than $850 \mathrm{~m}$ across the small sandy submarine fans and stratigraphically equivalent shelf-edge deltas off East Corsica. An earlier interpretation of the boomer profiles was presented by Pichevin (2000) and Pichevin et al. (2003). The seismic-reflection profiles cover an area of about $1240 \mathrm{~km}^{2}$ (Fig. 1). Seventeen strike lines, spaced about $1.4 \mathrm{~km}$, extend across the outer shelf, slope, and basin floor. Six other profiles, with an average spacing of $10 \mathrm{~km}$, extend normal or oblique to the shelf and slope. The Huntec fish was towed at a depth ranging from 30 to $120 \mathrm{~m}$ with a firing rate ranging from 600 to $1050 \mathrm{~ms}$ and a survey speed of about $4 \pm 0.5$ knots $(7.2 \mathrm{~km} / \mathrm{hour})$. Digital data were filtered to include frequencies between 900 to $7000 \mathrm{~Hz}$, with analog copies of profiles collected at a quarter-second sweep $(250 \mathrm{~ms})$. Vertical resolution is approximately $0.5 \mathrm{~m}$, horizontal resolution is $<100 \mathrm{~m}$, and penetration depth varies from a few metres in sand or gravel prone areas to more than $75 \mathrm{~m}$ in predominantly muddy areas. Track lines were positioned using GPS, and are accurate to within $30 \mathrm{~m}$. Digital SEGY files were corrected for delay offsets and loaded into Geoquest IESX, a seismic interpretation software package. Both paper copies and digital data were used for interpretation. Horizontal measurements from analogue and digital profiles were corrected for variations in ship speed and firing rate. Tracked horizons were checked at all crossover points to ensure the accuracy of correlations. Depth conversions used an acoustic velocity of $1500 \mathrm{~m} / \mathrm{s}$. 
Huntec acoustic facies classification

Previous studies have shown that the acoustic response on Huntec boomer profiles strongly reflects subsurface variations in lithology and, for finer grained lithologies in particular, bedding continuity (King \& Fader, 1986). A similar acoustic facies classification to that used by Piper et al. (1999) is used in this study (Fig. 2, Table 1), and is summarized below. Facies classes are differentiated according to reflection geometry, continuity, and amplitude. The abruptness the acoustic signal attenuation with increasing depth provides additional information about the average gain-size of the overburden. Typically, thick intervals of coarse-grained material (sands or gravel) significantly limit acoustic penetration.

Acoustic facies I and II correspond to intervals of continuous and parallel low and medium amplitude reflections, respectively. These facies are predominantly muddy, with the progressive increase in reflection amplitude interpreted to correspond to increasing frequency and thickness of silt and perhaps fine sand beds. In some cases facies I and II may represent purely pelagic or hemipelagic deposits with varying amounts of calcareous sediment. Acoustic facies III corresponds to intervals of continuous, parallel to sub-parallel or convergent high-amplitude reflections. Such reflections usually pass laterally either into facies II and I or into facies VI and VII (described below). Acoustic facies III is interpreted to be sand prone, consisting of nonamalgamated beds that thin laterally, separated by continuous muddy beds. Acoustic penetration is typically good in intervals of acoustic facies I, II, and III.

Acoustic facies IV corresponds to intervals of incoherent low backscatter reflections, commonly capped by moderate to low-amplitude hyperbolic reflections, with little or no attenuation of underlying reflections (a divergence from the classification scheme of Piper et al., 1999). Such intervals are interpreted as muddy debrites or slides with irregular upper surfaces and locally erosive bases. Only a few occurrences have been recognized in the shallow stratigraphic section of the study area (see Gervais et al., 2006). Acoustic facies $V$ corresponds to intervals of highamplitude, irregular to hyperbolic reflections interpreted to indicate small-scale channels, scours or coarse-grained bedforms (e.g. sand or gravel waves). Facies $\mathrm{V}$ commonly overlie facies $\mathrm{VI}$ and VII, particularly in areas where the local gradient increases. Acoustic facies VI corresponds to intervals of mixed chaotic and discontinuous to moderately continuous high-amplitude reflections. This facies is a hybrid of acoustic facies III and VII, with distinct stratification observed within an overall chaotic high-backscatter facies, with some attenuation of the acoustic signal with depth. It is interpreted to correspond to intervals of alternating amalgamated sand beds and nonamalgamated mud, silt, and sand beds. Facies VII corresponds to intervals of high-amplitude, incoherent chaotic facies that strongly attenuate the acoustic signal with depth. The incoherent character of this facies type is interpreted to be caused by sand-on-sand contacts associated with amalgamation surfaces, and is not interpreted to indicate bedding continuity. Both facies VI and VII show fairly abrupt lateral facies changes to more continuous facies (e.g. III).

\section{Proximal to distal changes in boomer stratigraphy}

\section{Outer Shelf}

Multiple stacked progradational units up to $20 \mathrm{~m}$ thick characterize the outer shelf (Fig. 3a, b). They have offlap breaks in water depths ranging from 50 to $140 \mathrm{~m}$, and on dip profiles are separated by wedge-shaped intervals that thicken in the landward direction (typically facies I, II, III). Despite the shallow water depths, acoustic penetration is relatively poor on the outer shelf, usually less than $40 \mathrm{~m}$, implying relatively coarse lithologies. Distinct bi-directional progradation (Fig. 3a) suggests that some of these depositional bodies consist of isolated fluvial-dominated deltaic lobes that built out onto the outer shelf at times of lower relative sea level. Both the topsets and bottom-sets of these units can be correlated into unconformities, which are particularly evident on dip profiles that cross the present-day shelf-break. 
Patches of acoustic facies VII locally characterize the top-sets of some progradational units, forming $<500 \mathrm{~m}$ wide and 5-10 m thick mounds or ridges. Based on multiple crossings on seismic profiles they have elongated planform geometries. The southern part of Fig. $3 a$ crosses obliquely over one of these ridges. Attenuation of the underlying acoustic signal implies coarser-grained lithologies, and we thus interpret them as sand-prone bars or shoals. The heads of the North and South Golo canyons and several smaller canyons to the north extend back onto the outer shelf, incising the shelf break. Progradation of shelf-edge deltas into the canyon heads and margins provided a direct link between fluvial-deltaic systems and submarine fans during periods of lower relative sea level.

\section{Slope}

Acoustic penetration increases on the slope (locally exceeding $75 \mathrm{~m}$ - Fig. 3c, d) indicating a predominance of finer grained lithologies (Figs. 3c, d). The slope can be divided into two morphological regions to the north and south of the Pineto gully (Figs. 1, 3c, d): a wider slope extending into deeper water to the south and a narrower slope extending into shallower water to the north.

Slope south of the Pineto gully

South of the Pineto gully the slope is 8 to $10 \mathrm{~km}$ wide and has an average gradient of $3.1^{\circ}$. The first break in slope occurs at about the $700 \mathrm{~m}$ isobath, where the gradient decreases to about $1.6^{\circ}$, and continues to decrease to $0.8^{\circ}$ approaching the flat-lying Golo Basin. Reflection continuity is very high, and seismic reflections can commonly be correlated from progradational units on the outer shelf to the slope and into the Corsican Trough (hence providing a link between delta and basin stratigraphy). Only rarely is the slope truncated by narrow V-shaped gullies (e.g. Fium Alto and Pineto) and a more extensive failure scarp just south of the study area (Gervais et al., 2004). The South Golo Canyon is deeply incised on the upper slope (170 m deep and $3.5 \mathrm{~km}$ wide) and lacks sediment fill (Gervais et al., 2004). High-amplitude reflections (acoustic facies VII) characterize its floor and terraces consisting of more continuous strata are found locally along its margins (e.g. Figs. 3b, c). On the lower slope (Figs. 4a, b), the canyon passes into a more aggradational fan valley flanked by wedge-shaped outer levees and is partially filled by aggradational high-amplitude channel deposits (facies VII) flanked by lower amplitude inner levees (facies II, III) forming stepped depositional terraces (Pichevin et al. 2003; Deptuck et al., 2003).

\section{Slope north of the Pineto gully}

In contrast to the slope in the southern study area, the slope north of the Pineto gully is much narrower (less than $4 \mathrm{~km}$ wide), reflecting a progressive northward shallowing of the toe-of-slope. The first break in slope (from $3.0^{\circ}$ to $1.5^{\circ}$ ) occurs at the $450 \mathrm{~m}$ isobath at the Pineto gully (compared with the $700 \mathrm{~m}$ isobath farther south). Further north, the break in slope occurs at about the $400 \mathrm{~m}$ isobath near the North Golo Canyon and at about the $300 \mathrm{~m}$ isobath north of the Biguglia Canyon (Fig. 1). Truncation of slope seismic reflections north of the Pineto gully prevents correlations of deposits on the outer shelf to basinal fans (Figs. 3c-d, 5). Like the South Golo Canyon, the North Golo Canyon forms a prominent, largely empty incision on the upper slope (Fig. 3b), but it passes very abruptly (just $1.5 \mathrm{~km}$ to the east) into a leveed fan valley on the lower slope, with a fill similar to the South Golo fan valley (e.g. Figs. 3c, d, 4a). The canyons farther north are less than $1 \mathrm{~km}$ wide, smaller than both the North and South Golo canyons and only slightly larger than the Fium Alto and Pineto gullies (Fig. 1a).

\section{Toe-of-slope and proximal basin floor}

The North and South Golo fan valleys continue beyond the toe-of-slope onto the proximal basin floor, where the regional gradient ranges from 1.0 to $1.5^{\circ}$. Here, positive bathymetric relief is the result of overbank deposition adjacent to the main conduits. In contrast to the South Golo fan valley, which remains an open conduit at the present-day sea floor, the North Golo fan valley 
passes abruptly from an open conduit (Fig. 4a) to a filled conduit (Fig. 4b) over a distance of 1.4 $\mathrm{km}$. The abrupt transition is caused by deposits of acoustic facies V, VI, and VII that plugged it just beyond the toe-of-slope.

The width of the slope, and hence the distance from the shelf-break to the first major reduction in gradient, varies from $10 \mathrm{~km}$ in the southern study area to less than $3 \mathrm{~km}$ in the northernmost study area. The $1.5^{\circ}$ decrease in gradient at the toe-of-slope commonly coincides with an increased occurrence of acoustic facies III, VI, and VII and a dramatic decrease in acoustic penetration (less than $40 \mathrm{~m}$ ), particularly north of the North Golo fan valley (see northern part of Fig. 4a). Here, several lens-shaped deposits of varying size are found clustered near the toe-ofslope, separated by more continuous seismic reflections (e.g. Figs 4a-c, 5). They were supplied by the Biguglia, St. Damiano, or other small erosive conduits that debouched near the toe-ofslope. Similar deposits plugged the proximal parts of the North Golo fan valley, and are found near the toe-of-slope at the termination of the Fium Alto and Pineto gullies. They are interpreted as submarine lobes (Pichevin, 2000; Gervais, 2002; Deptuck, 2003).

Some channels in the northern study area also continue onto the basin floor. The erosive St. Damiano channel appears to have been active recently (Fig. 4a-c), whereas the Fiuminale channel is covered by a blanket of acoustic facies I and II, interpreted as hemipelagic mud, indicating an extended period of inactivity (e.g. Figs. 4c-e). The margins of both channels are erosive, flanked by poorly developed or no overbank deposits that produce little positive levee relief at the seafloor.

\section{Basin floor to basin plain}

The relief associated with the North and South Golo fan valleys diminishes to the east. Starting at about the $600 \mathrm{~m}$ isobath several large stacked sedimentary bodies are recognized east of the North Golo fan valley and other narrower northern channels like Biguglia, St. Damiano, and Fiuminale (Figs. 1, 4e-g, 5). Likewise, starting at about the 700 to $800 \mathrm{~m}$ isobath several additional stacked sedimentary bodies are found east and south of the South Golo fan valley (Figs. 1, 6). Gervais at al. (2004) interpreted these sedimentary bodies as channel-termination lobes, similar to those described from Hueneme Fan by Piper et al. (1999). They consist of a combination of acoustic facies III, V, VI, and VII, and are locally separated from each other by more continuous seismic reflections. They pass laterally and distally into continuous seismic reflections of acoustic facies I, II and III (e.g. Figs. 4h, i). On the basin plain, lower amplitude acoustic facies I and II are dominant with penetration depths up to $95 \mathrm{~m}$, indicating principally finer-grained lithologies (e.g. distal parts of Figs. 5a, 6a).

\section{Lobe measurements}

Twenty sub-circular to elongate (plan view) and lens-shaped (cross-sectional) 'lobes' were mapped using boomer profiles (Fig. 1). They include those found near the toe-of-slope and those found at the termination of larger, more stable fan valleys. Repeated crossings of the same depositional bodies were used to measure spatial changes in their dimensions, geometry and architecture. This allows a quantitative comparison of lobes in the study area. Several measurements were made for each lobe (Fig. 7). Width (w) was measured from profiles approximately perpendicular to the long-axis of depositional bodies. Where profiles cross lobes obliquely, width was corrected for obliquity. Lobe length (I) measurements are minimums; a \pm 1 $\mathrm{km}$ error bar is used to capture the uncertainty in lobe length in both the up-slope and down-slope direction that result from the spacing of seismic profiles. Identification of the lateral and distal termination of lobes is in places subjective, especially where there are gradual facies changes into non-lobe deposits. Most lobe boundaries are defined as the position where there is no detectable thinning away from the lobe axis, commonly accompanied by a change in acoustic facies. In distal lobe settings where fringe deposits are commonly more parallel-bedded, a change in acoustic facies (commonly from III to II) defines the lateral limits of the lobe. 
Lobe area was measured from their interpreted outlines, derived from 2D seismic profiles. A $20 \%$ error estimate accounts for uncertainty in the position of the lobe perimeter. For some lobes the length (l'), width ( $\left.\mathrm{w}^{\prime}\right)$, and area (a') of the predominantly chaotic facies (VII) was also measured (Fig. 7). This was only possible for the smaller lobes located near the toe-of-slope, but is generally more precise than the total lobe dimensions and includes their most voluminous and probably sandiest parts. Lateral changes in thickness (h) were measured from profiles normal to the lobe long-axis, from which average and maximum lateral thinning rates were calculated $\left(\mathrm{Q}_{\mathrm{I}}\right)$. $\mathrm{A} \pm 1 \mathrm{~m}$ error accounts for uncertainty in near-seafloor imaging (e.g. bubble pulse), the accuracy of the time to depth conversion, and in some cases difficulty determining the base of thicker lobes (near the channel-mouth), which are poorly imaged due to attenuation of the acoustic signal. Proximal to distal thinning rates $\left(\mathrm{Q}_{\mathrm{p}-\mathrm{d}}\right)$ were determined from changes in maximum lobe thickness (Tmax) derived from each profile crossing a given lobe.

\section{General trends}

A wide range of lobe dimensions is observed. They cover areas ranging from 3 to $70 \mathrm{~km}^{2}$ (Fig. $8 \mathrm{a}$ ), have total lengths that vary from about 2 to greater than $14 \mathrm{~km}$ (Fig. 8d), and maximum widths that range from $1 \mathrm{~km}$ to greater than $10 \mathrm{~km}$ (Fig. 8c). Most lobes increase abruptly downslope to a peak thickness, beyond which they show a more gradual decrease in thickness until thinning below seismic resolution or passing into lower amplitude draping strata of the basin plain (acoustic facies I and II - Fig. 9). The locus of maximum sediment accumulation varies from 3 to $28 \mathrm{~km}$ from the shelf-break (Fig. 8b), indicating a wide range in transport efficiency of submarine sediment gravity flows. In some cases lobe thickness increases rapidly from zero to peak thicknesses just beyond the toe-of-slope. Larger lobes show a more gradual transition from leveed fan valleys and reach peak thicknesses much farther into the basin. Many lobes show a change in proximal to distal thinning rate (Fig. 9) that coincides with an increase in reflection continuity towards the distal part of lobes.

Several measured attributes were cross-plotted and examined for general trends. Thicker lobes tend to be more aerially extensive (Fig. 8a) but the relationship is not linear. Thicker lobes tend to be longer (Fig. 8d) as do wider lobes, with length to width ratios ranging from 1 to 3 (Fig. 8c). Length to width ratios are smaller for acoustic facies VII, measured from the proximal lobes, i.e. acoustic facies VII is more sub-circular in plan view. There is only a weak trend of increasing width with increasing thickness, with thickness to width ratios ranging from 0.001 to 0.0065 (Fig. 10). Maximum thickness versus width of acoustic facies VII shows a stronger relationship (Fig. 10), tending to be thicker and narrower than the more distal deposits dominated by acoustic facies III, which are generally broader and thinner. Potential causes for these general relationships will be discussed in more detail in later sections.

\section{Lobe classification}

Based primarily on their location, dimensions, and internal architecture, but also considering the nature of the feeder channel, two types of lobes are recognized. Small lobes are located in proximal settings on the slope or near the toe-of-slope, outboard from slope channels or gullies. Larger composite lobes are deposited in more distal settings, outboard from stable leveed fan valleys. An area of $25 \mathrm{~km}^{2}$ and a transport distance of $15 \mathrm{~km}$ from the shelf-break were used as arbitrary cut-off values to separate the two types of lobes. However, the lobes on either side of these arbitrary cut-off values may show characteristics common to both types of lobes (described below), and hence are hybrids.

Smaller lobes near the toe-of-slope

Eleven small lobes, referred to here as proximal isolated lobes (PILs), were mapped in this study. PILs consist of small, elongate to sub-circular deposits on the slope or near the toe-of-slope (Fig. 
1a). They commonly form at the termination of small short-lived (Gervais, 2002) linear to curvilinear slope gullies or channels. PILs occur 2.5 to $16 \mathrm{~km}$ from the shelf-break, rarely extend more than $7 \mathrm{~km}$, and have areas of 2 to $19 \mathrm{~km}^{2}$. Their length to width ratios range from $<1$ to 2 . They reach a maximum thickness of 9 to $20 \mathrm{~m}$ near the mouth of the erosional conduit, typically between 3 and $6 \mathrm{~km}$ from the shelf-break, but as much as $12 \mathrm{~km}$ where the slope is widest (e.g. Fium Alto lobe). PILs are located on the lower slope or near the first prominent break in slope, where there is a change in gradient from $3.0^{\circ}$ to about $1.5^{\circ}$. The location of maximum sediment accumulation typically occurs between 0 and $2.5 \mathrm{~km}$ from the toe-of-slope, decreasing in thickness abruptly down-slope (i.e. they form wedges on dip profiles - e.g. Figs. 5, 11). They thus pinch out upslope from the basin-floor of the North and South Golo fans. The highest concentration of PILs is clustered near the toe-of-slope in the northern study area (e.g. northern part of Fig. 4a, western part of Fig. 5a).

\section{Acoustic facies architecture}

PILs show relatively predictable proximal to distal and lateral changes in acoustic facies. The proximal thickest parts of PILs consist predominantly of acoustic facies VII, which passes laterally and distally into acoustic facies III, which in turn may grade laterally (over distances of 0.5 to 1 $\mathrm{km}$ ) and distally (over distances of 1 to $3 \mathrm{~km}$ ) into very thin facies II deposits or thin below seismic resolution (e.g. Figs. 12a, 13). Acoustic penetration decreases markedly below the thickest parts of PILs. Acoustic facies VII commonly comprises about $50 \%$ of their total planform area, covering 1.3 to $11.2 \mathrm{~km}^{2}$, and acoustic facies III typically comprises about $50 \%$ of their length (distal part, e.g. Figs. 5c, 11). Acoustic facies VII however, comprises more than $75 \%$ of the total volume of PILs.

Locally the lateral fringe of individual proximal isolated lobes shows distinct backstepping and onlap onto the impinging slope (e.g. Fig. 5b). Typically no progradation is observed. Some lobes show subtle up-flow migrating bedforms in the distal fringe (e.g. acoustic facies III - Fig. 5c), interpreted as sand-prone sediment waves. The distal parts of some PILs fill subtle, pre-existing bathymetric depressions. For example, the lobe in Fig. 12b was confined by subtle remnant relief above an older abandoned and draped leveed channel system. Its more basinward extent may have been caused by flow confinement resulting in longer run-out distances than would have been possible without confinement.

\section{Type example - Pineto lobe}

The Pineto lobe is considered the type example for PILs off East Corsica (Figs. 11, 13). It covers an area of about $11 \mathrm{~km}^{2}$, with its thickest parts (corresponding to acoustic facies VII) covering an area of about $4.5 \mathrm{~km}^{2}$. Two linear channels are present along its upper surface near the toe-ofslope (Fig. 4a). At least three or four separate beds can be identified within the lobe-fringe deposits (acoustic facies III), but cannot be distinguished in the main body of the lobe where beds may be amalgamated (facies VII) (Fig. 13). The Pineto lobe reaches a maximum thickness of 19 $\mathrm{m}$ near the toe-of-slope at the mouth of the Pineto gully, $2.5 \mathrm{~km}$ from the shelf-break, abruptly decreasing in thickness to $1.5 \mathrm{~m}$ over a distance of $6 \mathrm{~km}$ (Fig. 11). Hence, the most abrupt deposition takes place within a few kilometers of the gully mouth.

The Pineto lobe has an average proximal to distal thickness decrease of $2.92 \mathrm{~m} / \mathrm{km}$ (over the entire $8 \mathrm{~km}$ length of the lobe) with a maximum rate of $4.7 \mathrm{~m} / \mathrm{km}$ between 4 and $7 \mathrm{~km}$ from the gully mouth (steepest slope on Fig. 11b), where thick deposits of facies VII pass abruptly into thinner deposits of facies III. The $1.5^{\circ}$ decrease in gradient at the toe-of-slope, combined with the abrupt loss of confinement at the end of the gully, appears to have been sufficient to promote rapid deposition, and the resulting thickness of the deposit produces an asymmetric bell shaped curve (e.g. Figs. 11) analogous to slope-break deposits documented by Mulder \& Alexander (2001a). Although the main body of the lobe is generally tabular, the maximum lateral thinning rate, normal to the length axis of the Pineto lobe, is very high. At $1.5 \mathrm{~km}$ from the gully mouth the Pineto lobe thins laterally from $18 \mathrm{~m}$ (acoustic facies VII) to $2 \mathrm{~m}$ (acoustic facies III) over a 
distance of $800 \mathrm{~m}$ (thinning rate of $20 \mathrm{~m} / \mathrm{km}$ ). At 3.1, 4.7, and $7.9 \mathrm{~km}$ from the gully mouth, the maximum lateral thinning rate decreasing from 15 to 5 to $2.5 \mathrm{~m} / \mathrm{km}$, respectively.

Piston core calibration

Acoustic facies VII is a boomer response that is typical of massive, probably amalgamated, sand beds (Piper et al., 1999). The abrupt attenuation of the acoustic signal below the thickest parts of PILs implies thick intervals of coarser grained sediment. The lack of reflection continuity implies a lack of continuous lithological boundaries (e.g. Figs. 12a, 13). Piston core Kco55 targeted acoustic facies VII on the proximal part of the Pineto lobe, below a thin mud drape consisting of acoustic facies I (Fig. 11a). The corer penetrated $2 \mathrm{~m}$ of mud with only a few $\mathrm{cm}$ of penetration into the underlying sand. A second core was attempted at the same location with the same result. Piston core Kco56 targeted the thinner, distal part of the Pineto lobe (acoustic facies III and VI, encased above and below by acoustic facies I and II) (Fig. 11a). The corer recovered $9 \mathrm{~m}$ of sediment, including nearly $2 \mathrm{~m}$ of coarse massive to laminated sand with rare $\mathrm{cm}$-scale silt intraclasts. The distal Pineto lobe consists of at least 4 separate sharp-based beds with gradational to erosive upper contacts, separated by thin $\mathrm{cm}$-scale mud beds. This corroborates observations from boomer profiles that indicate the Pineto lobe was constructed from multiple flows. Piston core Kco57, $1.5 \mathrm{~km}$ down slope from Kco56, penetrated only mud within acoustic facies I and II (Fig. 11). No fine-grained turbidite facies were penetrated in the core (Gervais et al., 2006).

Two other piston cores sample acoustic facies VII within the small proximal lobes. Kco72 through the youngest, channel-plugging North Golo lobe penetrated over $4 \mathrm{~m}$ of massive, amalgamated coarse-grained sands with abundant silt intraclasts (Fig. 14). Kco 77 (Fig. 1b) penetrated $3.3 \mathrm{~m}$ of continuous massive to laminated coarse-grained sands in the Fium Alto lobe.

Larger composite lobes outboard major fan valleys

Nine larger composite lobe bodies, extending 15 to $36 \mathrm{~km}$ from the shelf-break, were mapped in more distal locations than PILs. These lobate bodies are referred to here as 'composite mid-fan lobes' (CMLs) because they are located in mid-fan settings (near the termination of fan valleys, sensu Normark, 1978) and commonly contain two or more higher-order stacked depositional bodies (lobe-elements), each separated by erosive surfaces or subtle onlap surfaces. In the upper $75 \mathrm{~m}$ of strata, four CMLs are located outboard the South Golo fan valley (A3, B3, C3, D3), three are located outboard the North Golo fan valley (A2, B2, C2), and two are located outboard narrower, erosive channels like Fiuminale and St. Damiano (A1, C1) (Figs. 1, 4f-j).

CMLs are on average much larger than PILs, covering areas ranging from 30 to $70 \mathrm{~km}^{2}$ and reaching a maximum thickness of 25 to $40 \mathrm{~m}$ just outboard from the mouths of fan valleys, between 16 and $25 \mathrm{~km}$ from the shelf-break (Figs. 8a-b). They have been correlated for distances of 8 to $14 \mathrm{~km}$ beyond the fan valley mouth (Fig. 8d), and their most distal parts reach the deepest water depths along the axis of the Corsican Trough (Fig. 1a). Their length to width ratios range from 1.4 to 2.8. Like the more proximal lobes, CMLs show a progressive decrease in thickness with increasing distance from the fan valley mouth (Fig. 9). The rate of thickness decrease, however, is more variable, and appears to reflect, in part, differences in the basin floor bathymetry beyond the fan valley mouth where the gradient varies from about $1.5^{\circ}$ to less than $0.5^{\circ}$. The thinning rate perpendicular to the length-axis of larger composite lobes can be very high, particularly in their proximal parts where lateral thinning rates as high as $15 \mathrm{~m} / \mathrm{km}$ are observed on some profiles (e.g. CML A2 decreases from $28 \mathrm{~m}$ thick at its crest, to less than $5 \mathrm{~m}$ thick at its flank, over a distance of $1.5 \mathrm{~km}$ - Fig. $4 \mathrm{~g}$ ). Like the smaller lobes, the lateral thinning rate typically diminishes with increasing distance from the fan valley mouth.

Acoustic facies architecture

CMLs consist of a complex arrangement of acoustic facies II, III, V, VI, and VII. Acoustic facies V, $\mathrm{VI}$, and VII are most common near the mouths of fan valleys (e.g. Figs. 4f-h, 6), whereas acoustic 
facies III and II are most common in distal settings where the lobes begin to pass into the basin plain (e.g. Fig. 4j, 6b). Correspondingly the acoustic penetration is lowest upstream and greatest downstream. Despite these general trends, the distribution of acoustic facies is more variable and less predictable than in PILs. Near the fan valley mouth, CMLs are dominated by intervals of incoherent (VII) or hyperbolic (V) acoustic facies (e.g. Fig. 15c), separated by more continuous reflections or intervals of acoustic facies III or VI. Erosive discontinuities within facies VI and VII are common (e.g. Figs. 4f-h - lobes $\mathrm{C} 1$ and $\mathrm{C} 2$ ). They define the boundaries of higher order lobeelements, representing a shift in the locus of lobe deposition with erosion of, and onlap onto, underlying and adjacent lobe deposits. In some cases, intervals of acoustic facies I and II that otherwise may have draped the lobe appear to have been eroded during the formation of such discontinuities (e.g. Figs. 15b, d). Deeper erosional features are also observed. A $7 \mathrm{~m}$ deep elongate depression cuts the southern part of CML C2 (Fig. 15c), and two similar features cut CML B3 (Figs. 4g-i). They are interpreted as scours or erosive distributary channels that were later draped by mud-prone deposits dominated by acoustic facies I. In some cases they may be flanked by more aggradational sandy "overbank" deposits. Despite being blanketed by 7 to $17 \mathrm{~m}$ of drape, they still form elongated depressions on the modern seafloor, lending themselves to reoccupation should future flows encounter them. Together these features characterize what is interpreted to be equivalent to the 'channel-lobe transition' (Mutti \& Normark, 1987, 1991; Wynn et al., 2002).

Continuous, well-stratified, acoustic facies II and III are best developed at the distal fringes of CMLs. In some cases the steep slope along the eastern margin, together with the southern plunge of the Corsican Trough, deflected the distal fringe deposits to the south (Gervais et al., 2004), whereas the thicker proximal parts of larger lobes appear unaffected by the confining western margin. Some ponding of distal lobe-fringe deposits is also observed at the distal end of CMLs C3 and D3 (cumulatively referred to as the South Golo lobe by Gervais, 2002) (Fig. 6a). Locally, thin lens-shaped deposits are recognized within the fringe deposits (e.g. Fig. 6b). These may be equivalent to the low-gradient lobe sub-elements described by Piper et al. (1999). Hyperbolic reflections (facies $\mathrm{V}$ ) are also recognized locally in more distal settings where they are associated with steeper dipping portions of lobes (e.g. Figs. 6c, e). Such facies could be associated with the reworking of underlying deposits as flows accelerated in response to locally increased gradients, generating scours or coarse-grained bedforms.

The area of acoustic facies III, interpreted as lobe-fringe deposits, commonly makes up about 40 to $50 \%$ of the total lobe area, with the majority located in the distal part of the lobe, outboard from acoustic facies V, VI, and VII. Facies types with greater reflection continuity like III and VI constitute as much as $50 \%$ of the total lobe volume of CMLs, much higher than in PILs.

\section{Type example - North Golo CML C2}

The youngest distal lobe located outboard the North Golo fan valley, CML C2, is considered the type example. It covers an area of about $53 \mathrm{~km}^{2}$ and has an estimated length of $12 \mathrm{~km}$. It attains it maximum thickness of $27 \mathrm{~m}$ about $16 \mathrm{~km}$ from the shelf-break (measured along the North Golo fan valley - Fig. $4 \mathrm{~g}$ ), diminishing to $10 \mathrm{~m}$ an additional $12 \mathrm{~km}$ into the basin, resulting in an average proximal to distal thinning rate of $1.42 \mathrm{~m} / \mathrm{km}$ (lower than most PILs). Multiple scours and other erosional features characterize the proximal part of CML C2. Near the fan valley mouth, successive reflections backstep and onlap the adjacent sloping basin floor, a geometry that is similar to the northern part of Fig. 6a (CML C3). Such geometries could indicate lobe retreat, during the passage of progressively smaller or less efficient flows, or could simply indicate a progressive lateral shift in lobe deposits towards the adjacent slope. Backstepping beds plugged much of the relief of the North Golo fan valley during aggradation of CML C2, leaving little seafloor expression of the former valley (e.g. Fig. 4f). Like other lobes, on vertically exaggerated boomer profiles CML C2 has a prominent lens-shape cross-sectional motif near the fan valley mouth (where it thins from $19 \mathrm{~m}$ at the crest to $2 \mathrm{~m}$ on its flank - Fig. 4h), but diminishes to a broader, much more tabular motif down-flow. Moving progressively farther into the basin, the average lateral thinning rate of CML C2 diminishes from 11.3 to $9.8,5.8$, and $2.0 \mathrm{~m} / \mathrm{km}$. The distal fringes of CML C2 show migration of what appear to be sediment waves that developed above subtle pre-existing irregularities from an underlying lobe (Fig. 4j, 16a). 
Piston core calibration

The progressive down-fan increase in acoustic penetration reflects the general down-flow thinning of CMLs and may also indicate a decrease in sand content (compare CML C2 in Figs. 4fj). Piston core Kco71 directly outboard of the mouth of the North Golo fan valley penetrated nearly $5 \mathrm{~m}$ of continuous massive coarse-grained sands, probably consisting of a series of amalgamated beds (Fig. 14). Hence, as in the PILs, the more reflective and chaotic proximal acoustic facies consists of thick sand-prone intervals associated with rapid deposition at the termination of the fan valley. In contrast, Kco66 from the distal fringe of C2 (acoustic facies II and III) sampled four normally graded $\mathrm{dm}$-scale coarse to fine sand beds separated by mud beds. Hence, the distal parts of CMLs consist of largely non-amalgamated and tabular sheet-like lobe to muddy basin plain deposits. Intervals of acoustic facies III probably correspond to sheet-sands that would be considered outer fan 'lobes' in traditional outcrop studies (e.g. Mutti \& Ricci Luchi, 1972; Mutti, 1979). Their feathered-edge termination probably closely coincides with the pinch-out of sheetsands (e.g. Figs. $5 \mathrm{~d}, 6 \mathrm{a}, 16$ ), with the down-flow passage into acoustic facies II and I probably corresponding to the transition from lobe-fringe to mud-dominated basin plain deposits (e.g. Mutti, 1977). The acoustic facies trends probably indicate that the mud-rich parts of flows continued into the Corsica Trough after the sands fell out of suspension (see also Remacha et al., 2005).

\section{Discussion}

Hierarchy of compensation stacking

Compensation stacking (Mutti \& Sonnino, 1981) occurs at a variety of scales in the lobe deposits off East Corsica, from gradual shifts in successive beds to abrupt offsets in stacked composite lobes. At least three hierarchical levels of compensation stacking are recognized, which together define a depositional hierarchy that can be used to understand lobe architecture. Beds or bedsets stack to form lobe-elements; lobe-elements stack to form composite lobes; and composite lobes stack to form lobe complexes (Fig. 17). Each hierarchical level is defined according to the abruptness of the shift between the thickest parts of successive bodies (lateral or proximal to distal), the relative importance of bounding discontinuities (defined by erosion, baselap, or abrupt vertical changes in acoustic facies) and the amount of drape between depositional bodies (best preserved beyond the channel-lobe transition). Multiple crossings of lobes at varying distances from the shelf-break are needed to define this hierarchy, and hence it may be difficult to recognize a similar hierarchy in outcrops without widespread and repeated exposure.

Compensation stacking within lobe complexes

Lobe complexes, as defined here, consist of stacked composite lobes that are fed by the same primary conduit (Fig. 17). Abrupt lateral shifts from one CML to another (in a lobe complex) are probably initiated by relatively large channel-mouth avulsions that redirect the sediment supply, hence substantially changing the region of thickest sediment accumulation. We refer to this process as composite lobe compensation.

Both the North and South Golo fan valleys feed lobe complexes (Fig. 1a). The North Golo fan valley for example initially fed CML $A 2$, but a channel-mouth avulsion to the north led to deposition of CML B2 above and adjacent to it. The channel-mouth in turn avulsed back to the south where CML C2 was deposited in the bathymetric low between A2 and B2 (e.g. Fig. 4h). During successive channel-mouth avulsions, the locus of thickest sediment accumulation shifted laterally by 3 to $5 \mathrm{~km}$, with the magnitude of the shift probably depending on the geometry (including relief) of the abandoned composite lobe and the pre-existing basin floor morphology outboard the new fan valley mouth. Off East Corsica a relatively large channel-mouth avulsion took place every 10-14 ky during the last fall to maximum lowstand in sea level. This estimate is 
based on the 3 or 4 CMLs deposited in about 40 ky between reflectors I and $\mathrm{K}$ (age control from Gervais, 2002).

Composite lobe switching may be prompted by both autocyclic processes and the passage of abnormally large flows. The boundary between CML C3 and D3, for example, is overlain by $a>2$ $\mathrm{m}$ thick low-relief lens-shaped bed located far out into the Golo Basin (Fig. 6b). It was probably deposited during the passage of a particularly vigorous flow that prompted an abrupt westward shift in deposition. Some degree of autocyclicity probably also played a role, as earlier deposits consistently aggraded and migrated in the opposite direction, building up the gradient on the western side of CML C3 (e.g. Fig. 6d). CML D3 is quite narrow compared to other composite lobes (see Fig. 8c) because it was constricted to the east by the steep flank of CML C3 and to the west by the muddy slope off East Corsica, providing only a relatively narrow corridor in which turbidites could accumulate.

Abandoned CMLs may be blanketed by several metres of hemipelagic and muddy turbidite drape, consisting of acoustic facies I and II. The drape is commonly eroded in the channel-lobe transition (e.g. between B2 and C2 in Fig. 4f, g), but is increasingly preserved down-flow (e.g. Figs. 4h-j). Much of the drape above one $\mathrm{CML}$ is time-equivalent to active deposition in an adjacent CML. Examination of CMLs B3 (South Golo) and C2 (North Golo) in Fig. 4 supports this idea. Reflections at the top of the older CML B3 correlate laterally into deposits at the base of the younger CML C2 (Fig. 4j), indicating that no major breaks in active lobe deposition took place. A similar relationship is observed between CML B2 and C2 (i.e. the muddy fringe of C2 blankets the top of B2). As such, the drape between CMLs does not necessarily represent a period of quiescence and long-term basin-wide absence of sediment gravity flows, but instead may represent a substantial shift in the locus of active deposition, with more condensed strata draping inactive CMLs.

\section{Compensation stacking within composite lobes}

Composite lobes, as defined here, consist of two or more higher-order depositional bodies (lobeelements) separated by disconformable surfaces, thin drapes, or abrupt vertical shifts in acoustic facies (Fig. 17). Within composite lobes, lobe-elements stack in an apparently arbitrary pattern, with shifts in position inferred to result from a change in channel-mouth position due to smallscale avulsions or channel migration. We refer to this process as lobe-element compensation.

Lobe-element compensation within CMLs in some cases shows two hierarchical orders of stacking. Simpler composite lobes like B3 can be subdivided into two narrow lobe-elements that diverge down-flow (B3a and B3b - Fig. 4). More complex CMLs like C1 can be subdivided into two depositional bodies ( $\mathrm{C} 1 \mathrm{a}$ and $\mathrm{C} 1 \mathrm{~b}$ ), which in turn can be subdivided into multiple higher-order lobe-elements (labelled 1 to 10, Fig. 15b). Each lobe-element probably represents the deposits from a number of flows with relatively similar properties. The processes that control lobe-element switching are similar to the processes that control composite lobe switching, differing only in the magnitude and probably the frequency of the shift in deposition. Lobe-element switching may be initiated by a change in flow properties, causing a 500 to $2000 \mathrm{~m}$ advance, retreat, or lateral offset in the locus of deposition at the fan valley mouth. The average time-span for lobe-element switching off East Corsica is difficult to estimate, but is probably $<5 \mathrm{ky}$. Increased frequency of particularly vigorous flows may triggering more frequent switching and increase the architectural complexity of some composite lobes. Autocyclic processes may also prompt lobe-element switching once some threshold in bed compensation (described below) is reached, forcing a change in the depocenter without requiring a change in flow properties. In experiments by Parsons et al. (2002), lobe-element switching occurred when the confining sides of the lobe were steeper than the downstream gradient, inducing an increase in the head velocity of turbidity currents down the lateral lobe flank, generating an erosional discontinuity.

\section{Compensation stacking within lobe-elements}

Lobe-elements, as defined here, can consist of isolated bodies, as in the Pineto lobe, or nested bodies within a composite lobe (as described above). They are comprised of contiguous stacks of beds or bed-sets, lacking any major lobe-wide discontinuities on boomer seismic profiles (Fig. 
17). Beds and bed-sets typically show systematic $<500 \mathrm{~m}$ shifts in the locus of the thickest deposit, with successive seismic reflections commonly stepping backwards or sideways. This process is referred to here as bed compensation.

Some reflections, particularly those near the base of lobes, aggrade with only minor shifts in bed position. More common, however, are seismic reflections that aggrade with contemporaneous lateral or backwards shifts. In PILs and in lobes within CMLs, bed compensation is most easily observed in the lateral fringes on seismic profiles oriented parallel or oblique to the lobe axis, where beds progressively onlap as they impinge on the slope or inclined basin floor (e.g. Figs. 5b, $6 e$ ). Side-stepping beds on a given seismic profile may generate apparent retrogradation (Fig. 16c) or progradation (Fig. 16d) as beds move away from one location and toward another. In outcrops this would produce a vertical succession that resembles an upward-thinning and fining cycle along one lobe fringe (e.g. Fig. 16c) that is time-equivalent to an upward-thickening and coarsening vertical succession on the conjugate fringe (e.g. Fig. 16d) (see also Chen \& Hiscott, 1999). Hence, both vertical successions may develop coevally, and detailed mapping is required to distinguish such lateral shifts from true progradation and retrogradation.

Sideways shifts in the locus of successive beds are probably caused by the subtle morphological influence of the preceding deposit on the trajectory of succeeding flows, and are similar to the gradual development of deposit asymmetry documented by Parsons et al. (2002). After an initial period of aggradation in their experiments, a strong asymmetry developed (after 8-10 flows) as the preferred flow path veered from the center-line of the initial aggradational lobe. True backstepping of beds may develop through a progressive change in flow properties (e.g. decrease in flow volume), but may also develop in response to a decrease in gradient along the flow path, prompting flows to decelerate and deposit some of their load (e.g. Mulder \& Alexander, 2001a; Kubo, 2004). In numerical models of tubidity currents by Pratson et al. (2000), up-flow migrating beds developed in response to flow deceleration and forced deposition as successive flows attempted to cross over the depositional 'bulge' created by the previous deposit (see their Fig. 11). A slight up-flow shift in the break in slope after each 'slope-break deposit', therefore, will prompt progressive backwards shifts in the beds without requiring a change in input flow parameters. Bed-scale 'back-stepping' is particularly evident in lobe fringes where successive seismic reflections migrate in a manner that appears similar to sediment waves documented on levees (e.g. Figs. 5c, 6c, 16a) (e.g. Migeon et al., 2001; Normark et al., 2002).

Controls on the location, dimensions, and architecture of lobes

The wide variations in lobe deposits off East Corsica probably reflect a number of interrelated factors including a) flow properties (e.g. volume, composition, duration, velocity), b) the number and frequency of flows, and their degree of variation through time, c) seafloor configuration at the mouth of the feeder conduit (which may divert, reflect, and constrict flows - Gervais et al., 2004) and abruptness of breaks in slope, d) lobe lifespan prior to avulsion or abandonment, and e) feeder channel geometry and stability (influencing distance and degree to which flows remained confined). Using multiple lines of evidence, the factors responsible for differences in the location, dimensions, and architecture of PILs and CMLs are explored in more detail below.

\section{Proximal isolated lobes}

Most PILs are architecturally simple and were probably constructed from a relatively small number of flows (e.g. piston core Kco56 penetrated four non-amalgamated sand beds on the distal fringe of Pineto lobe - Fig. 11). Piston cores Kco77 and Kco72 penetrated the thickest parts of the Fium Alto and proximal North Golo lobes, respectively. The lack of normal or inverse grading and the abundance of floating mud clasts in the massive sands lead Gervais et al. (2006) to interpreted the sands as deposits from short-duration (surge-like) sand-laden hyperconcentrated flows (sensu Mulder \& Alexander, 2001b) with a thick basal laminar layer and poorly developed upper dilute part. Deposition from such flows is dominated by frictional freezing. The absence of levees adjacent to the Pineto gully (even on the lower slope) is consistent with relatively thin flows (<30 $\mathrm{m}$ thick) with a poorly developed upper dilute layer. Because it takes time for levees to form, the absence of levees may also reflect the relatively small number of 
flows contributing to PILs. The lack of turbidites in Kco57 (Gervais et al., 2006), located only 1.5 $\mathrm{km}$ down-flow from $\mathrm{Kco56}$ (which penetrated $2 \mathrm{~m}$ of sand in the Pineto lobe fringe), however, indicates flows had short run-out distances and either lacked an upper dilute part or the dilute part bypassed Kco57 and deposited thin beds elsewhere where they are too thin or indistinct to identify on boomer profiles.

The small dimensions of PILs (Figs. 8c-d) and the apparent lack of equivalent deposits in the basin plain are consistent with relatively small volume sand-laden flows (see numerical experiments by Pratson et al., 2000). Flume tank experiments by Baas et al. (2004) showed inverse relationships between grain size and deposit length and width. They found that coarsergrained flows produced narrower deposits with shorter run-out distances and more abrupt thinning rates. Al Ja'aidi et al. (2004) and others have also shown that short run-out distances may be due to highly concentrated flows where turbulence is suppressed by grain interactions (see also Mulder \& Alexander, 2001b). Hence, the narrow widths, short run-out distances, and very high maximum thinning rates of PILs are also consistent with coarse-grained and highly concentrated flows, hence supporting observations from piston cores.

The more proximal position of PILs is probably related to flow expansion at the gully mouth or due to flow deceleration where the gradient decreases at the toe-of-slope, causing a critical loss of capacity in flows overloaded with sediment (Normark \& Piper, 1991; Hiscott, 1994; Mulder \& Alexander 2001a; Kubo, 2004). This includes the youngest channel-plugging North Golo lobe, which despite having been supplied by the North Golo fan valley, was deposited as an isolated lobe near the toe-of-slope, above the largely filled North Golo fan valley (filled by backstepping deposits of CML C2) (Figs. 1a, 4b-d).

The very abrupt lateral (up to $20 \mathrm{~m} / \mathrm{km}$; Fig. 13) and proximal to distal (up to $5 \mathrm{~m} / \mathrm{km}$ ) thinning of acoustic facies VII implies that rapid deposition by frictional freezing dominated the thickest, most proximal parts of most PILs. Minor development of lamination in sand at the thinner distal fringes of PILs (e.g. at Kco56 on the Pineto lobe; Fig. 11), however, may indicate deposition from progressive grain settling takes place with increased transport distance. Although the dimensions and thinning rates are much different, this situation is analogous to the abrupt streamwise transition from thick sandy debrites to thin high density turbidite beds with traction structures documented in the Marnoso-arenacea Formation by Amy et al. (2005).

\section{Composite mid-fan lobes}

CMLs are larger, more distal and architecturally complex depositional bodies than PILs. They were probably built by a larger number of flows, which could account for their thicker and more aerially extensive deposits and better developed levees. Stable fan valleys provided a longerterm link between the sediment source area and the depocenter, hence allowing more flows to transport sediment to the same general area before a major avulsion (i.e. before composite lobe switching). The increased distance over which flows remained confined by fan valleys could account for their more distal position compared to PILs. Channel adjustments towards a graded profile (via aggradation, incision, or variations in sinuosity - Pirmez et al., 2000) would also have allowed longer transport distances by reducing the abruptness of gradient changes along the flow path. Hence, it seems clear that the larger area, length, and width of CMLs was caused by the cumulative effects of lobe-element switching (proximal to distal and lateral offset), and their more distal position reflects, at least in part, the distance over which flows remained confined. But were there also differences in the properties of flows that supplied CMLs compared to PILs?

The presence of thick muddy levees indicates that flows supplying CMLs periodically transported turbulently suspended mud sufficiently high in the flow (> $50 \mathrm{~m}$ above channel floor) to overspill levee crests. In addition, erosive features in the channel-lobe transition are prevalent in most CMLs, indicating many flows were fully turbulent upon exiting the North and South Golo fan valleys. Furthermore, the proximal to distal transition from chaotic, high-backscatter acoustic facies (V, VI, VII) to relatively thick intervals of well-stratified lobe-fringe to basin plain deposits (I, II, III) in CMLs, are consistent with sediment gravity flows that deposited their coarsest load near the channel-mouth (like PILs), but with the remaining fines (i.e. the fines that were not deposited on muddy levees) carried in more dilute turbidity currents into the Corsican Trough. Piston cores Kco71 (thick coarse-grained sands in the proximal part of CML C2) and Kco66 (multiple thin 
normally graded sand beds separated by mud beds $18 \mathrm{~km}$ down-flow), are consistent with this interpretation (Fig. 14). Common hyperbolic reflections above sandy lobe deposits may have formed from reworking and winnowing during the passage of the more dilute part of the flow toward the lobe fringe and basin plain (see Sylvester \& Lowe, 2004).

These observations suggests that CMLs were periodically supplied by two-layer flows (e.g. bipartite turbidity currents of Mutti et al., 2003), with a dense basal layer that deposited sands proximally and a thick dilute upper part that deposited sand and mud distally or on levees in more proximal settings (see also Gervais et al., 2006). Hence, the average flows supplying CMLs may have had different properties than flows supplying PILs. However, it is difficult to distinguish between differences in input flow parameters and differences due to changes in flow properties that took place during transport. Flow confinement and increased transport distance, for example, may have influenced flow evolution by progressive entrainment of ambient seawater, providing more time for a thicker dilute upper part to develop during transport (varying the character of flows exiting the fan valley mouth, without necessarily requiring a change in flows initiated in the canyon head).

Where individual lobe-elements in CMLs could be mapped with the present data set (e.g. B3a and B3b in CML B3), they are quite narrow and longer than most PILs (Fig. 8c). Baas et al. (2004) showed that finer-grained flows spread deposits over larger areas, were longer, and thinned more gradually. Similarly, increasing the initial size of flows in numerical models by Pratson et al. (2000) and flume tank experiments by Al Ja'aidi et al. (2004) also produced more elongated deposits that covered larger areas. Hence lobe-elements B3a and B3b are consistent with more voluminous, longer duration, or muddier flows. Lobes mapped by Gervais (2002) in CML D3 using lower resolution sparker profiles (her Figure VI-24) showed a wider range of aspect ratios, which may indicate that CMLs are supplied by a wide variety of flows.

\section{Outer shelf evolution and potential influence on flow initiation}

Flow properties are strongly influenced by the types of sediment in the source area and the triggering mechanism for submarine sediment gravity flows, which in turn influence flow composition and duration (Piper \& Normark, 2001). Sea level position may strongly influence which triggering mechanisms dominate through time (e.g. Piper et al., 1999, Normark et al., 2006). Hence information from the sediment source area and its response to sea level changes may help constrain temporal and spatial variations in flow types (provided that shelf deposits can be linked to fan deposits).

\section{Lobes constructed during falling sea level}

Throughout the Pleistocene the Golo River supplied sand and mud to a relatively narrow shelf, and at times of lower sea level or high sediment discharge, it transported sediment to the shelf edge in the form of shelf-edge deltas. All of the CMLs discussed in this paper were deposited between reflectors I and $\mathrm{K}$, during the last fall to maximum lowstand in sea level (MIS 2-4 Gervais, 2002). Direct seismic correlation from basinal areas onto the shelf indicates widespread progradation took place on the outermost shelf while CMLs were deposited. Forced regression caused shelf-edge deltas to advance seaward and into the heads of submarine canyons (Figs. $3 a, 18)$ in response to falling sea level that culminated about $21 \mathrm{ka}$ at the last glacial maximum (LGM). The deepest offlap breaks of the prograding deltas range from 104 to $110 \mathrm{mbsl}$ (Fig. 18), consistent with sea level position at the LGM (Chappell \& Lambeck, 2001).

The Golo River is a high-gradient 'dirty' river and according to Mulder \& Syvitski (1995), such rivers periodically may generate hyperpycnal flows during hinterland floods. When sea level was high, sediment from hyperpycnal flows was probably trapped on the shelf. During periods of low sea level, however, when the mouth of the Golo River was located near the shelf-break (and near canyon heads), sediment would have been discharged directly onto steeper gradients, increasing the potential for fluvial underflows to continue as turbidity currents into the Corsican Trough. Like Gervais et al. (2004, 2006), CMLs are interpreted in this study to have been supplied, at least in part, by turbidity currents initiated by hyperpycnal flows. Increased sediment suspension and turbulence production at the base of slope during the passage of sustained hyperpycnal flows 
(see Gray et al., 2005, 2006) could explain why sediment supplied to CMLs was transported beyond the toe-of-slope even before levees aggraded (in contrast to PILs whose thickest deposits closely coincide with to first major break in slope). Sustained flows with a mixed composition are well suited for constructing thick muddy levees (Piper \& Normark, 2001). In submarine fans like the Var (Piper \& Savoye, 1993), Laurentian (Piper et al. 2006) and Hueneme (Piper et al., 1999), the passage of prolonged muddy hyperpycnal flows, on which the Coriolis effect is strong, is interpreted to have promoted levee asymmetry (Piper \& Savoye, 1993). Similar processes may be responsible for the levee asymmetry of the North and South Golo fan valleys.

During floods the Golo River probably transported a mixture of sand and mud to canyon heads. Al Ja'aidi et al. (2004) found that increasing the volume of fines increased transport distance by reducing the settling velocity of the coarser fraction (i.e. flows were more efficient - Mutti, 1979). Sediment in such mixed flows is partitioned into four areas. The coarser fraction accumulates on the channel-floor or near the mouth of the main feeder channel, and the finer-grained fraction is either deposited on the levees or continues to flow towards the lobe-fringe and into the basin plain. Hyperpycnal flows, however, are unlikely to have been the only types of flows initiated during falling sea level. Although progradation of shelf-edge deltas into canyon heads (Fig. 3a) confirms a direct linkage with fluvial systems during falling sea level (forced regression), this observation is insufficient to distinguish between flows triggered by direct input from the Golo River and flows generated after a temporary period of storage in the canyon head. River-mouth failures of well sorted sandy mouth bars or muddy prodelta deposits (or a combination of the two) triggered by rapid sediment loading, canyon head flushing (e.g. Mastbergen \& Van den Berg, 2003), or rip-currents (Normark \& Piper, 1991) could have supplied some flows to CMLs. Similarly, canyon-margin failures triggered by seismicity are also possible. Hence, although hyperpycnal flows are suspected to be a primary contributor of sediment to CMLs, flows from a wide variety of sources were possible, and such variability, combined with their longer life-spans (Gervais, 2002), may explain the complex architecture of many CMLs.

Lobes constructed during rising sea level

During the rise in eustatic sea level that followed the LGM (post reflector K - Gervais et al., 2004), the architecture of the outer shelf was complex, consisting of isolated delta lobes (labelled ' $A$ ' and ' $B$ ' in Fig. 18b) and condensed intervals where transgressive reworking generated sandy shoals or bars (Fig. 3a). The smaller gullies that fed the Pineto and Fium Alto lobes were incised only when the rising sea had already inundated the outer shelf and they appear unconnected to rivers on land (Gervais et al. 2004). Delta lobe 'A' is perched on the middle shelf and did not reach the shelf-edge. It is thus unlikely to have directly supplied the Pineto lobe. The space between the delta bottom-sets and the true shelf-break, however, was exposed to shelf currents and wave action and, as suggested by Gervais et al. (2006), likely experienced intense reworking and winnowing of fines (e.g. Fig. 18e). Hyperpycnal flows then are unlikely to be the dominant triggering mechanism for flows. Likewise, the initiating process for sand transport down the gullies is not likely to have been rip-current suspension and ignitive flow of the type found in southern Californian canyons that head in the surf zone. Such ignitive flow is highly erosive and turbulent and in the well-known case of La Jolla fan eroded a lengthy fan valley, depositing sand far out on the basin floor (Piper, 1970). Instead, the Pineto lobe, and other PILs, may consist of sediment derived from the failure of sandy shoals located near the shelf-break (e.g. Figs. 3a-b, 18b), reworked and pre-sorted by waves and shelf-currents during rising sea level (Normark \& Piper, 1991).

The Fium Alto gully taps into an outer shelf bar or shoal of acoustic facies VII, and similar morphological features are located near the heads of the Pineto gully and Biguglia Canyon further north (Fig. 18b). Reflector $\mathrm{K}$ at the base of the Fium Alto lobe was correlated into the most distal clinoforms of the shelf-edge delta that appear laterally contiguous with a sandy shoal above the delta top-sets. The youngest clinoforms have high amplitudes and may have formed from the 'washed over' of sand from the shoal during wave reworking. A prominent wave-cut platform on the seaward side of the sandy shoal confirms wave action was important during early transgression (Fig. 18f). Flows could have been initiated by oversteepening of sand transported to the gully head by shelf processes, analogous to periodic failures known from prograding fan- 
deltas (Syvitski et al. 1986), or in response to storm waves or ground shaking by earthquakes. The small Dume fan off southern California contains other examples of proximal lobes showing inefficient sand transport (Normark et al. 1998). Dume fan consists of several stacked rapidly thinning wedges of acoustic facies VII, interpreted as massive sands and referred to as 'highgradient lobes' by Piper et al. (1999). The massive sands were sorted within the littoral drift cells prior to triggering of sediment gravity flows, and are remote from direct fluvial input. As with the Pineto lobe, Dume Fan does not appear to have contributed significant basin-floor mud, although it does have low levees (similar to Fium Alto).

Not all flows initiated during the last transgression were sourced from pre-sorted sediment on the outer shelf. The two isolated delta lobes, with offlap breaks between 50 and $80 \mathrm{mbsl}$, indicate some links to fluvial systems were maintained during transgression. The deltas prograded either in response to a decrease in the rate of eustatic sea level rise (as would have been the case during the Younger Dryas), or a temporary increase in sediment supply (perhaps during the melting of alpine glaciers). Therefore when sea level was between 80 and $50 \mathrm{~m}$ below present day levels, the same flow initiation mechanisms that were active during low sea level may have been active, at a more local scale, during rising sea level where deltas temporarily prograded into canyon heads (e.g. mixed-load hyperpycnal flows or river mouth failures of sandy mouth bar and muddy prodelta deposits). For example, clinoforms from delta lobe 'A' prograded into the South Golo Canyon from the north (Figs. 3a, 18b), and may have supplied some flows to the youngest submarine lobe of the South Golo fan (lobe 'E3' - Fig. 1a), which is time-equivalent to the Fium Alto and Pineto lobes. Lobe E3 was deposited in a distal location and has a well-developed sandmud lobe fringe that extends well out into the Golo Basin, and hence its boomer character is similar to other lobes found in CMLs. It is not known if some flows were also initiated from the failure of the sandy shoal south of the canyon.

\section{Conclusions}

1. Twenty lens-shaped (cross-section) and lobate (planform) depositional bodies were identified, mapped, and measured in this study. Two populations of lobes were defined based on their location, architecture, and nature of the feeder conduit. Proximal isolated lobes (PILs) are found on the slope or near the toe-of-slope and were supplied by gullies or erosive channels. They are smaller, architecturally simple, and pinch-out abruptly laterally and down system. Composite midfan lobes (CMLs) are found in more distal locations, outboard of stable conduits like the North and South Golo leveed fan valleys. They are larger and architecturally more complex (consisting of multiple nested lobes-elements), and commonly show more gradual thickness variations.

2. Differences in the size, shape, and architectural complexity of lobe deposits reflect several interrelated factors including a) flow properties (volume, duration, grain size, concentration, and velocity), b) the number and frequency of flows, and their degree of variation through time, c) gradient change and seafloor morphology at the mouth of the feeder conduit, d) lobe lifespan prior to avulsion or abandonment, and e) feeder channel geometry and stability.

3. The relatively simple architecture of PILs may reflect the shorter life-span, smaller number of flows feeding them, and narrower range in flow properties compared to CMLs. The more proximal position of PILs is probably related to flow expansion at the gully mouth or due to flow deceleration where the gradient decreases at the toe-of-slope, causing a critical loss of capacity in sandy flows overloaded with sediment. Most PILs were deposited while the outer shelf was inundated during the last transgression, and hence may have been supplied from inefficient surge-like flows triggered when sandy shoals or bars near the heads of gullies failed. Poor development of muddier lobe fringes and levees flanking the gullies of most PILs implies flows were thin and had a poorly developed upper dilute part either because the original flows contained little mud, or because the short transport distances did not provide enough time for a dilute upper layer to develop. Frictional freezing may dominate the thick, most volumetric up-flow 
parts of PILs, and more progressive grain settling, to varying degrees, may dominate their much thinner down-flow parts.

4. The more complex architecture of CMLs probably reflects the greater number and wider variety of flows that supplied them. The presence of outer levees flanking fan valleys, inner levees within fan valleys, and well-developed finer-grained lobe fringes, suggests that flows contributing to CMLs periodically had more suspended mud than flows supplying PILs. This could reflect the types of flows initiated in the canyon head, or differences in flow evolution (with increased confinement and transport distance providing more time for flows to develop a thicker dilute upper layer). Sustained mixed-load hyperpycnal flows were most likely to reach the Golo fan system when the river mouth was located near the shelf-break (or near a canyon head) during periods of low eustatic sea level, but surge-like flows were probably also triggered after a temporary period of storage in the canyon head, contributing to the architectural complexity of CMLs.

5. At least three hierarchical orders of compensation stacking are observed in CMLs off East Corsica: 1) beds or bed-sets stack to form lobe-elements through backwards or lateral shifts caused by the subtle bathymetric influence of previous deposits on subsequent flows (bed compensation); 2) lobe-elements stack to form composite lobes and lobe-element switching is initiated by minor channel-mouth avulsions or channel migration (Iobe-element compensation); and 3) composite lobes stack to form lobe complexes and switching is initiated by major channelmouth avulsions (composite lobe compensation). The abandonment of one depositional body for another during both composite lobe and lobe compensation could be initiated by a) changes in flow parameter, b) autocyclic controls once some threshold in bed stacking or lobe stacking is achieved, or c) a combination of the two.

\section{Acknowledgements}

Field acquisition of data was funded by IFREMER and the Canada Program for Energy Research and Development. While at Dalhousie University, Ph.D. funding for MED was provided by a Natural Sciences and Engineering Research Council of Canada (NSERC) post-graduate scholarship, a Fred A. Dix AAPG grant-in-aid, a supplemental NSERC scholarship from Natural Resources Canada, and David Piper's NSERC discovery grant. Shell is thanked for providing time for MED to prepare this article. Zoltan Sylvester, Ciaran O'Byrne and Carlos Pirmez are thanked for helpful discussions. The authors are grateful to Jan Alexander and Bill Normark whose reviews substantially sharpened the article. Geological Survey of Canada contribution number 20070110.

\section{References}

Adeogba, A.A., McHargue, T.R. and Graham, S.A. (2005) Transient fan architecture and depositional controls from near-surface 3-D seismic data, Niger Delta continental slope. AAPG Bulletin, 89, 627-643.

Al Ja'aidi, O.S., McCaffrey, W.D., and Kneller, B.C. (2004) Factors influencing the deposit geometry of experimental turbidity currents: implications for sand-body architecture in confined basins. In: Confined Turbidite Systems (Eds S.A. Lomas and P. Joseph), Geological Society London Special Publication, 222, 45-58.

Amy, L.A., Talling, P.J., Peakall, J., Wynn, R.B., and Arzola Thynne, R.G. (2005) Bed geometry used to test recognition criteria of turbidites and (sandy) debrites. Sedimentary Geology, 179, 163-174.

Baas, J.H., Kesteren, W.V. and Postma, G. (2004) Deposits of depletive quasi-steady highdensity turbidity currents: A flume analogue of bed geometry, structure and texture.

Sedimentology, 51, 1053-1088. 
Bellaiche, G., Droz, L., Gaullier, V. and Pautot, G. (1994) Small submarine fans on the eastern margin of Corsica; sedimentary significance and tectonic implications. Marine Geology, 117, 177185.

Chappell, J. and Lambeck, K. (2001) Sea level change through the last glacial cycle. Science 292, 679-686.

Chen, C. and Hiscott, R. N. (1999) Statistical analysis of trubidite cycles in submarine fan successions: Tests for short-term persistence. Journal of Sedimentary Research, 69, 486-504.

Deptuck, M. E. (2003) Post-rift geology of the Jeanne d'Arc Basin, with a focus on early Paleogene submarine fans, and insights from modern deep-water systems, Dalhousie University, Halifax, NS, Canada, Doctoral thesis, 369 pp.

Deptuck, M.E., Steffens, G.S., Barton, M. and Pirmez, C. (2003) Architecture and evolution of upper fan channel-belts on the Niger Delta slope and in the Arabian Sea. Marine and Petroleum Geology, 20, 649-676.

Fonnesu, F. (2003) 3D seismic images of a low-sinuosity slope channel and related depositional lobe (West Africa deep-offshore). Marine and Petroleum Geology, 20, 615-629.

Gervais, A. (2002) Analyse multi-échelles de la morphologie, de la géométrie et de l'architecture d'un système turbiditique sableux profond (Système du Golo, Marge est-Corse, Mer méditérannée), L'Universite Bordeaux, Doctoral thesis, 315 pp.

Gervais, A., Savoye, B., Piper, D.J.W., Mulder, T., Cremer, M., and Pichevin, L., (2004) Present morphology and depositional architecture of a sandy confined submarine system: the Golo turbidite system (eastern margin of Corsica). In: Confined Turbidite Systems (Eds S.A. Lomas and P. Joseph), Geological Society London Special Publication, 222, 59-89.

Gervais, A., Mulder, T., Savoye, B., Gonthier, E. (2006) Sediment distribution and evolution of sedimentary processes in a small sandy turbidite system (Golo system,

Mediterranean Sea): implications for various geometries based on core framework

Geo-Mar Letters, 26, 373-395.

Gray, T.E., Alexander, J. and Leeder, M.R. (2005) Quantifying velocity and turbulence

structure in depositing sustained turbidity currents across breaks in slope. Sedimentology, 52, 467488.

Gray, T.E Alexander, J. and Leeder, M.R. (2006) Longitudinal flow evolution and turbulence structure of dynamically similar, sustained, saline density and turbidity currents. Journal of Geophysical Research, 111, C08015 doi:10.1029/2005JC003089.

Hiscott, R. N. (1994) Loss of capacity, not competence, as the fundamental process governing deposition from turbidity currents, Journal of Sedimentary Research, A64, 209-214.

King, L.H. and Fader, G.B. (1986) Wisconsinan glaciation of the continental shelf, southeastern Atlantic Canada. Geological Survey of Canada Bulletin, 363, $72 \mathrm{p}$.

Kubo, Y. (2004) Experimental and numerical study of topographic effects on deposition from twodimensional, particle-driven density currents Sedimentary Geology, 164, 311-326.

Mastbergen, D. R. and van den Berg, J. H. (2003) Breaching in fine sands and the generation of sustained turbidity currents in submarine canyons, Sedimentology, 50, 625-637.

Migeon, S., Savoye, B., Zanella, E., Mulder, T., Faugeres, J. C., and Weber, O. (2001) Detailed seismic-reflection and sedimentary study of turbidite sediment waves on the Var sedimentary ridge (SE France); significance for sediment transport and deposition and for the mechanisms of sedimentwave construction, Marine and Petroleum Geology, 18, 179-208.

Mulder, T. and Alexander, J. (2001a) Abrupt change in slope causes variation in the deposit thickness of concentrated particle-driven density currents. Marine Geology, 175, 221-235.

Mulder, T. and Alexander, J. (2001b) The physical character of subaqueous sedimentary density flows and their deposits. Sedimentology, 48, 269-299.

Mulder, T. and Syvitski, J.P.M. (1995) Turbidity currents generated at mouths of rivers during exceptional discharges to the world oceans. J. Geol., 103, 285-299.

Mutti, E. (1977) Distinctive thin-bedded turbidite facies and related depositional environments in the Eocene Hecho Group (South-central Pyrenees, Spain). Sedimentology, 24, 107-131.

Mutti, E. (1979) Turbidites et cônes sous-marins profonds. In: Sédimentation détritique (fluviatile, littorale et marine) (Ed. P. Homewood), pp. 353-419. Institut géologique de l'université de Fribourg, Switzerland. 
Mutti, E. and Normark, W.R. (1987) Comparing examples of modern and ancient turbidite systems: problems and concepts. In: Marine clastic sedimentology (Eds J.K. Leggett and G.G. Zuffa), pp. 1-38.

Mutti, E. and Normark, W.R. (1991) An integrated approach to the study of turbidite systems. In: Seismic Facies and Sedimentary Processes of Modern and Ancient Submarine Fans (Eds P. Weimer and M.H. Link), Springer Verlag, New York, p. 75-106.

Mutti, E., and Ricci Lucchi, F. (1972) Le torbiditi dell' Appennino Settentrionale: introduzione all'analisi di facies. Memorie della Societa Geologica Italiana, 11,161-199.

Mutti, E., and Sonnino, M. (1981) Compensation cycles: a diagnostic feature of sandstone lobes. International Association of Sedimentologists, 2nd European Meeting, Bologna, Abstracts p. $120-123$.

Mutti, E., Tinterri, R., Benevelli, G., di Biase, D., and Cavanna, G. (2003) Deltaic, mixed, and turbidite sedimentation of ancient foreland basins, Marine and Petroleum Geology, 20, 733-755.

Normark, W.R. (1978) Fan valleys, channels, and depositional lobes on modern submarine fans; characters for recognition of sandy turbidite environments. AAPG Bulletin, 62, 912-931.

Normark, W.R. and Piper, D.J.W. (1991) Initiation processes and flow evolution of turbidity currents: implications for the depositional record. SEPM Special Publication 46, 207-230.

Normark, W.R., Piper, D.J.W. and Hess, G.R. (1979) Distributary channels, sand lobes, and mesotopography of Navy submarine fan, California Borderland, with applications to ancient fan sediments. Sedimentology, 26, 749-774.

Normark, W.R., Piper, D.J.W. and Hiscott, R.N. (1998) Sea level controls on the textural characteristics and depositional architecture of the Hueneme and associated submarine fan systems, Santa Monica Basin, California. Sedimentology, 45, 53-70.

Normark, W.R., Piper, D.J.W., Posamentier, H.W., Pirmez, C. and Migeon, S. (2002) Variability in form and growth of sediment waves on turbidite channel levees. Marine Geology, 192, 59-78.

Normark, W.R., Piper, D.J.W, and Sliter, R. (2006) Sea-level and tectonic control of middle to late Pleistocene turbidite systems in Santa Monica Basin, offshore California. Sedimentology, 53, 867-897.

Parsons J.D., Scheweller, W.J., Stelting, C.W., Southard, J.B., Lyons, W.J. and Grotzinger, J.P. (2002) A preliminary experimental study of turbidite fan deposits.

Journal of Sedimentary Research, 72, 619-628.

Pichevin, L. (2000) Etude sédimentaire et sismique d'un éventail turbiditique sableux: le systèm récent du Golo (Marge Est-Corse). DEA Environnements et Paléoenvironnements Cotiers et Océaniques, Université Bordeaux, $57 \mathrm{p}$.

Pichevin, L., Mulder, T., Savoye, B., Gervais, A., Cremer, M. and Piper, D.J.W. (2003) The Golo submarine turbidite system (east Corsica margin): morphology and processes of terrace formation from high-resolution seismic reflection profiles. Geo-Marine Letters, 23, 117-124.

Piper, D. J. W. (1970) Transport and deposition of Holocene sediment on La Jolla deep sea fan, California. Marine Geology, 8, 211-227.

Piper, D.J.W. and Normark, W.R. (1983) Turbidite depositional patterns and flow characteristics, Navy Submarine Fan, California Borderland. Sedimentology, 30, 681-694.

Piper, J.W.P., and Normark, W.R. (2001) Sandy fans - from Amazon to Hueneme. AAPG Bulletin, 85, 1407-1438.

Piper, D.J.W. and Savoye, B. (1993) Processes of late Quaternary turbidity current flow and deposition on the Var deep-sea fan, north-west Mediterranean Sea. Sedimentology, 40, 557-582.

Piper, D.J.W., Hiscott, R.N. and Normark, W.R. (1999) Outcrop-scale acoustic facies analysis and latest Quaternary development of Hueneme and Dume submarine fans, offshore California. Sedimentology, 46, 47-78.

Piper, D.J.W., Shaw, J. and Skene, K.I. (2006) Stratigraphic and sedimentological evidence for late Wisconsinan subglacial outburst floods to Laurentian Fan. Palaeogeography, Palaeoclimatology, Palaeoecology 246, 101-119.

Pirmez, C., Beaubouef, R.T., Friedmann, S.J., and Mohrig, D.C. (2000) Equilibrium profiles and baselevel in submarine channel: Examples from Late Pleistocene systems and implications for the architecture of deepwater reservoirs, In: Deep-water reservoirs of the world (Eds P. 
Weimer, R.M. Slatt, J. Coleman, N.C. Rosen, H. Nelson, A.H. Bouma, M.J. Styzen, and D.T. Lawrence), GCSSEPM Foundation $20^{\text {th }}$ Annual Research Conference, 782-805.

Pratson, L.F., Imran, J., Parker, G., Syvitski, J.P.M., and Hutton, E. (2000) Debris flows vs. turbidity currents: a modeling comparison of their dynamics and deposits. In: Fine-grained turbidite systems (Eds A.H. Bouma and C.G. Stone), AAPG Memoir, 72, 55-72.

Remacha, E., Fernandez, L. P., and Maestro, E. (2005) The transition between sheet-like lobe and basin-plain turbidites in the Hecho Basin (south-central Pyrenees, Spain). Journal of Sedimentary Research, 75, 798-819.

Sarg, J.F. and Skjold, L.J. (1982) Stratigraphic traps in Paleocene sands in the Balder area, North Sea. The deliberate search for the subtle trap. AAPG Memoir, 32, 197-206.

Shanmugam, G. and Moiola, R.J. (1991) Types of Submarine Fan Lobes - Models and Implications. AAPG Bulletin, 75, 156-179.

Stanley, D.J., Rehault, J.P. and Stuckenrath, R. (1980) Turbid-layer bypassing model; the Corsican Trough, northwestern Mediterranean. Marine Geology, 37, 19-40.

Sylvester, Z., and Lowe, D.R. (2004) Textural trends in turbidites and slurry beds from the Oligocene flysch of the East Carpathians, Romania: Sedimentology, 51, 945-972.

Syvitski, J.P.M., Burrell, D.C. and Skei, J.M. (1986) The fluvial deltaic environment. In: Fjords: Processes and Products, Springer, New York, Chapter 3.

Wynn, R.B., Kenyon, N.H., Masson, D.G., Stow, D.A.V., and Weaver, P.E. (2002) Characterization and recognition of deep-water channel-lobe transition zones. AAPG Bulletin, 86, 1441-1462.

\section{Table}

Table 1. Seismic facies classification scheme. CML - composite mid-fan lobe; PIL - proximal isolated lobe

\begin{tabular}{|c|c|c|c|c|}
\hline $\begin{array}{l}\text { Acoustic } \\
\text { facies }\end{array}$ & Acoustic character & $\begin{array}{l}\text { Piston } \\
\text { cores }\end{array}$ & Interpreted lithology & Setting \\
\hline I & $\begin{array}{l}\text { Parallel low-amplitude } \\
\text { continuous reflections. Normal } \\
\text { reduction in acoustic } \\
\text { penetration }\end{array}$ & $\begin{array}{l}\text { Kc066, } \\
\text { Kco67, } \\
\text { Kco56, } \\
\text { Kco57 }\end{array}$ & Mud with thin silt beds & $\begin{array}{l}\text { Basin plain muddy } \\
\text { turbidites to pelagic } \\
\text { drape, background } \\
\text { sedimentation }\end{array}$ \\
\hline II & $\begin{array}{l}\text { Parallel moderate-amplitude } \\
\text { continuous reflections }\end{array}$ & Kco66 & $\begin{array}{l}\text { Mud prone with decimetre } \\
\text { scale sand beds }\end{array}$ & $\begin{array}{l}\text { Distal lobe fringe to } \\
\text { background } \\
\text { sedimentation }\end{array}$ \\
\hline III & $\begin{array}{lr}\text { Parallel to sub-parallel high- } \\
\text { amplitude } \\
\text { reflections }\end{array}$ & $\begin{array}{l}\text { Kco56, } \\
\text { Kco66 }\end{array}$ & $\begin{array}{l}\text { Fine to coarse sands } \\
\text { separated by continuous } \\
\text { mud beds }\end{array}$ & $\begin{array}{l}\text { Lobe fringe on } \\
\text { PILs and CMLs }\end{array}$ \\
\hline IV & $\begin{array}{l}\text { Chaotic, low-amplitude to } \\
\text { transparent reflections, with } \\
\text { hyperbolic tops. No reduction } \\
\text { in acoustic penetration }\end{array}$ & na & Disorganized mud & Debrite, slide \\
\hline $\mathbf{V}$ & high-amplitude & na & Gravel (?) to coarse sand & $\begin{array}{l}\text { Channel-lobe } \\
\text { transition, } \\
\text { erosional scours or } \\
\text { small scale coarse- } \\
\text { grained bedforms }\end{array}$ \\
\hline VI & $\begin{array}{l}\text { Mixed stratified-chaotic high- } \\
\text { amplitude reflections. } \\
\text { Moderate reduction in } \\
\text { acoustic penetration. }\end{array}$ & Kco56 & $\begin{array}{l}\text { Coarse to medium } \\
\text { amalgamated sand beds } \\
\text { separated by discontinuous } \\
\text { mud beds }\end{array}$ & $\begin{array}{l}\text { Common in CMLs, } \\
\text { at transition to } \\
\text { lateral and distal } \\
\text { fringe }\end{array}$ \\
\hline VII & $\begin{array}{lr}\text { Chaotic } & \text { high-amplitude } \\
\text { reflections. } & \text { Significant } \\
\text { reduction } \\
\text { penetration. }\end{array}$ & $\begin{array}{l}\text { Kco72, } \\
\text { Kco71 }\end{array}$ & $\begin{array}{l}\text { Coarse to medium sand } \\
\text { beds, largely amalgamated }\end{array}$ & $\begin{array}{l}\text { Proximal lobe, near } \\
\text { channel mouth }\end{array}$ \\
\hline
\end{tabular}




\section{Figures}

Figure 1. a). Basemap showing east Corsican margin and location of canyons, channels, and 'lobes' discussed in this paper. Dashed lines show location of Huntec DTS boomer profiles. Fi Fium Alto lobe; Pi - Pineto lobe; NG - proximal North Golo lobe. Contours are from Stanley et al. (1980) and Bellaiche et al. (1994). Inset shows regional setting. b) Location of cores and Huntec seismic profiles discussed in text.

Figure 2. Type examples and descriptions of Huntec acoustic facies types I to VII.

Figure 3. a to d) Series of south to north oriented detailed line drawings from high resolution boomer seismic profiles. Line drawings are necessary because of the high background noise in boomer profiles, which prevent more than a few $\mathrm{km}$ of section to be shown in a journal figure without losing coherent reflections to background noise. The original analog profiles used to generate line drawings were much larger, with a vertical scale of $5 \mathrm{~cm}$ per $25 \mathrm{~ms}$ two-way time, and a horizontal scale of approximately $12 \mathrm{~cm}$ per $1 \mathrm{~km}$. Information about the amplitude of reflections is not preserved on the line drawings, and hence low-amplitude reflections look the same as high-amplitude reflections (the result is an artificial normalization of reflections enhancing subtle reflections and diminishing the prevalence of high-amplitude reflections). Variations in ship speed generate $a+/-5 \%$ error on the horizontal scale in all line drawings. The profiles are spaced roughly $1.4 \mathrm{~km}$ and cross the outer shelf $(a, b)$ and slope $(c, d)$.

Figure 4. Series of south to north oriented detailed line drawings from high resolution Huntec DTS seismic profiles across the toe-of-slope and extending onto the floor of the Corsica Trough. Profiles a) to e) show the North and South Golo fan valleys and other channels, as well as several stacked smaller proximal lobes. Profiles f) to j) show several large stacked composite mid-fan lobes. A1 and C1 were supplied by either the Biguglia or St. Damiano channels. A2, B2, and C2 were supplied by the North Golo fan valley. A3, B3, C3, and D3 (not shown) were supplied by the South Golo fan valley. More complete sections through C3 are shown in Figure 6. Inset shows line locations. See text for details. Boxes show figure locations.

Figure 5. a) West-southwest to east-northeast line drawing from boomer high resolution profile extending from the toe-of-slope to the floor of the Corsican Trough. Farthest west the profile crosses several small proximal lobes deposited near the first break in slope (near the toe-ofslope). Farther east the profile crosses the much larger A1 (deeper) and C1 (shallower) composite mid-fan lobes. b) Boomer profile showing backstepping and onlapping reflections on abruptly thinning fringe of a proximal isolated lobe. c) Boomer profile showing the down slope transition from acoustic facies VII to III in a proximal lobe, and backstepping bedforms on its distal fringe. d) Boomer profile across the lateral/distal fringe of CML C1. Note the backstepping and western onlap of seismic facies III and IV. e) Boomer profile near the toe-of-slope showing the stacking of several smaller proximal isolated lobes near the toe-of-slope.

Figure 6. Line-drawing boomer profiles across composite lobe C3 (eastern South Golo lobe). a) Profile roughly parallel to sediment transport direction, showing backstepping reflection consisting of acoustic facies $\mathrm{VI}$, passing distally into more continuous lobe fringe deposits consisting of acoustic facies III (in the Golo Basin). b) Close-up of fringe deposits showing low relief lens. c) Close-up of transition to lobe-fringe deposits. d) Profile crossing the lateral fringe of C3, with e) Close-up showing onlapping reflections onto sloping basin floor with both continuous and hyperbolic reflections. Note the climbing and backstepping of individual reflections, resulting in a gradual smoothing over of the gradient change between the impinging slope and the lobe.

Figure 7. Cartoon illustrating the types of measurements made from lobes in the study area.

Figure 8. Cross-plots of: a) Maximum lobe thickness versus lobe area. Note that thicker lobes tend to cover a larger area. b) Maximum lobe thickness versus distance from the shelf-break 
(measured along the feeder channel and the length axis of the lobe-form). Note that lobes show peak thicknesses that vary from $2 \mathrm{~km}$ to $>25 \mathrm{~km}$ from the shelf-break. c) Lobe width versus lobe length. d) Maximum lobe thickness versus lobe length.

Figure 9. Proximal to distal variations in lobe maximum thickness. Each point represents the maximum lobe thickness from a single seismic profile crossing a lobe at a given measured distance from the shelf-break. Most lobes increase abruptly down-slope to a peak thickness, beyond which they show a more gradual thinning with increasing distance.

Figure 10. Crossplot of maximum lobe thickness versus lobe width derived from all profiles that cross roughly normal to the long-axis of lobes in the study area. Each data point represents the measured width and maximum thickness from a single seismic profile normal to the long-axis of the lobe.

Figure 11. a) Schematic cartoon based on several boomer profiles that cross the Pineto lobe. Transects correspond to profiles shown in figures 4a-e. b) Plot showing down-flow changes in maximum thickness of Pineto lobe. c) Plot showing thickness variations normal to the Pineto lobe from five boomer profiles illustrated in (a). Note the abrupt decrease in thickness between transects $f$ and $g$. Piston cores penetrating the lobe are shown.

Figure 12. a) Huntec profile across one of the proximal isolated lobes, showing abrupt lateral thinning and limited development of lateral lobe fringe deposits. b) Profile across the distal end of the proximal Biguglia lobe. Note the confinement of acoustic facies VII, interpreted as amalgamated sands deposited within a depression, filling the remnant relief above an abandoned and draped leveed fan valley. See figure 4 for profile locations.

Figure 13. a) Huntec profile and b) corresponding line drawing across Pineto lobe, showing highbackscatter acoustic response (facies VII), interpreted as amalgamated sand beds. Note the prominent attenuation of the acoustic signal below the thickest part of the lobe. Location shown on figure 4b. c) Figures in this paper are typically shown with a vertical exaggeration of 20 to 25. Note that at a 1:1 scale, very little thinning is observed over a $1 \mathrm{~km}$ horizontal distance, an important consideration for comparisons to outcrop work.

Figure 14. a) Lithological plots from piston cores crossing the youngest North Golo PIL (Kco72) and older North Golo lobe outboard of the now-buried North Golo fan valley (Kco71, 67, 66). b) Schematic cartoon illustrating the interpreted lateral facies relationships between core locations based on boomer profiles. See Fig. 1b for location.

Figure 15. a) Uninterpreted and b) interpreted boomer profile across the C1 composite mid-fan lobe. Note the vertical changes in acoustic facies that probably result from proximal to distal shifts in lobe-element deposits. c) Prominent elongated scour or distributary channel above the channel-lobe transition of composite lobe C2. d) Removal of drape via erosion near the channellobe transition.

Figure 16. a) Boomer profile from distal fringe deposits of larger composite mid-fan lobes deposited outboard the North Golo fan valley. b) Dip-profile down CML A1 showing pinch-out of lobe and passage from facies III into finer-grained facies I and II of the basin plain. Note that there are areas of both apparent lobe advance and lobe retreat (c-e). These reflect gradual shifts from one lobe location towards another (and vice-versa), producing what would be upward-fining and thinning or upward-coarsening and thickening cycles in outcrops. The lower part of the lobe in (e) may represent true lobe progradation, as successive flows advanced into the Corsican Trough.

Figure 17. Schematic diagram showing the hierarchy of compensation stacking observed in composite mid-fan lobes. 
Figure 18. a) Outer shelf distribution of prograding clinoforms during the last fall to maximum lowstand in sea level when CMLs were deposited (correlated to the interval between reflectors I and $\mathrm{K}$ ). b) Outer shelf distribution of isolated deltaic lobes and sandy shoals or bars reworked during the last transgression when most PILs were deposited (above reflector K). c) to f) are line drawings from boomer profiles crossing the outer shelf. 
Unconformity

North

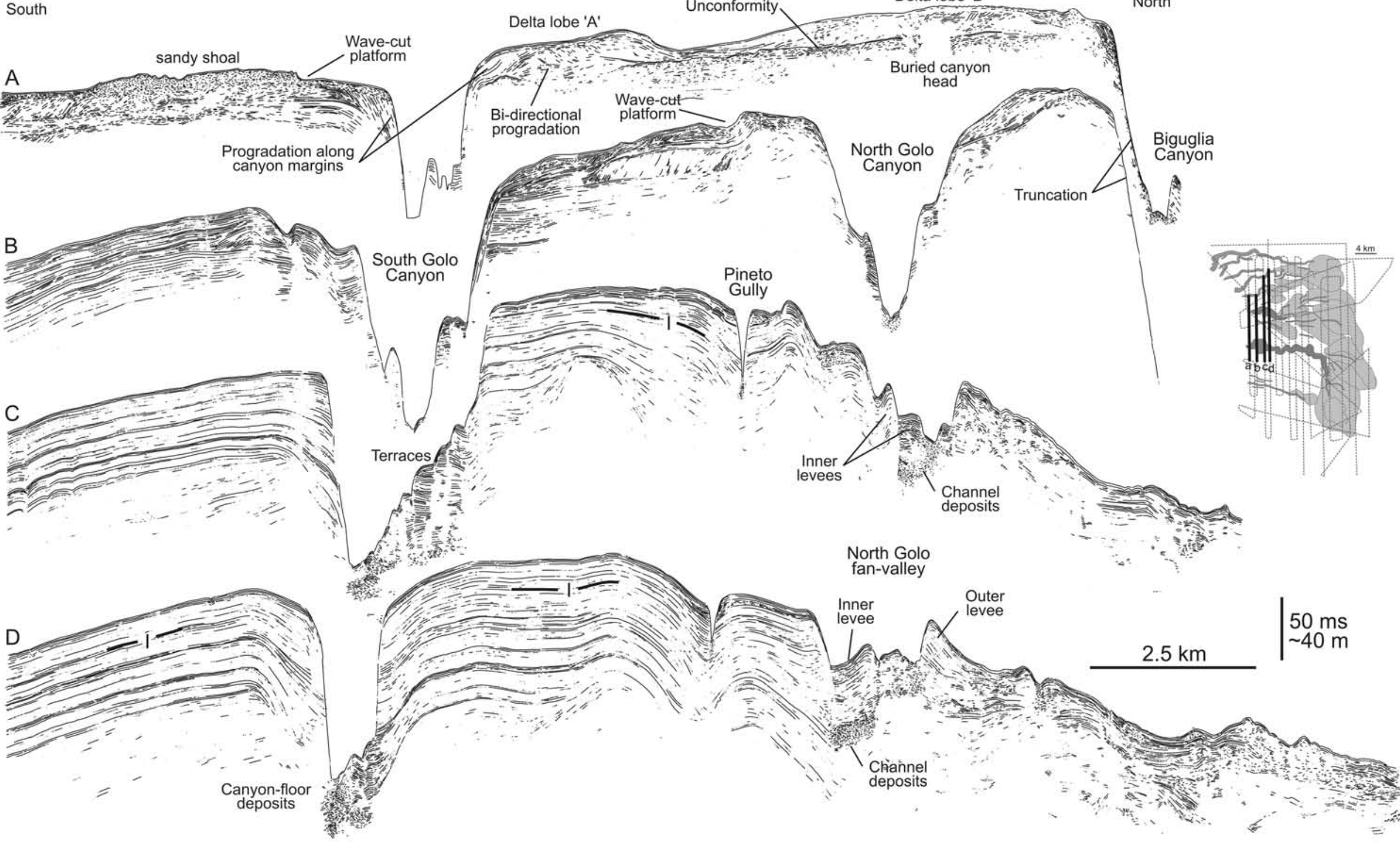




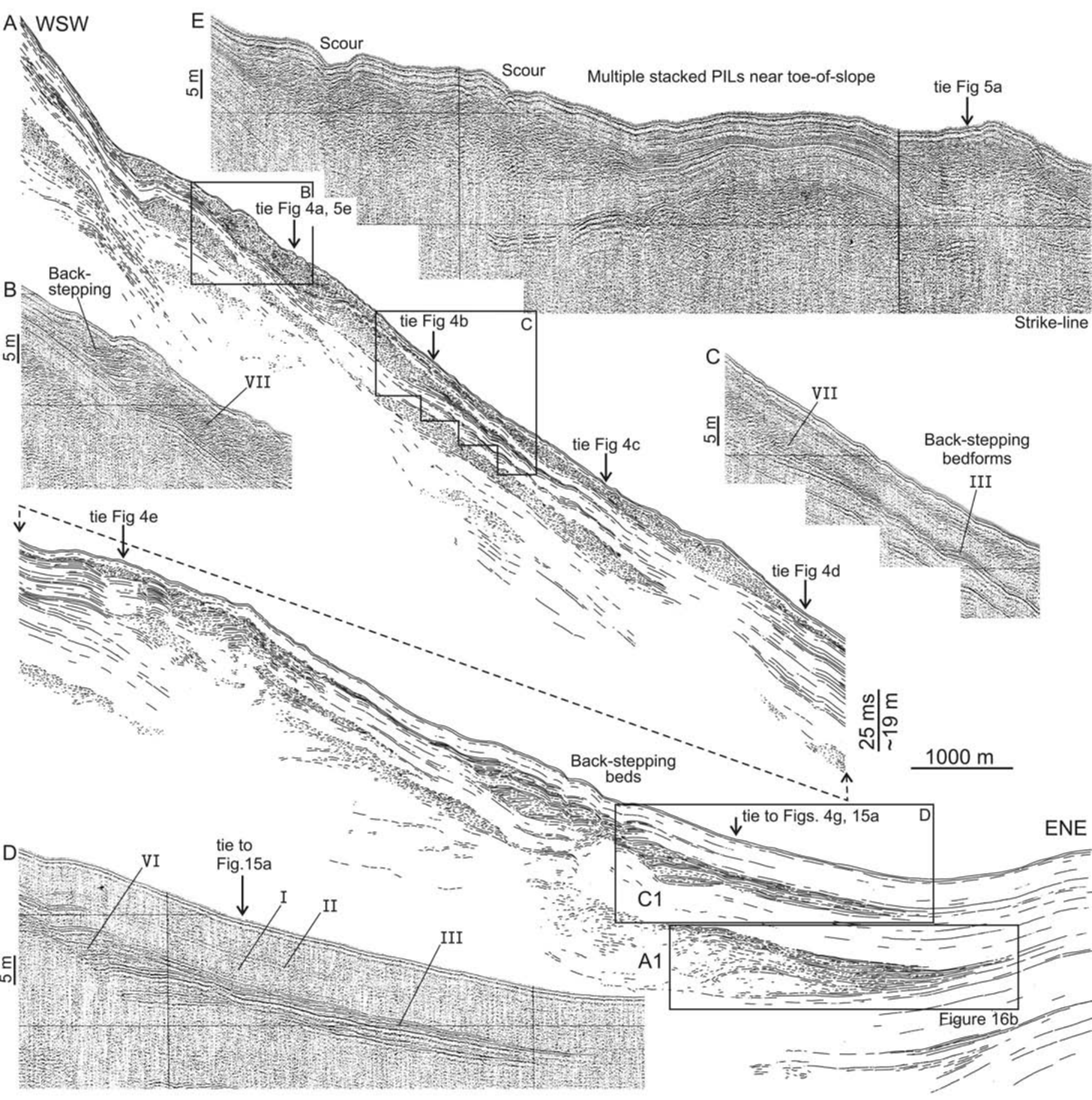





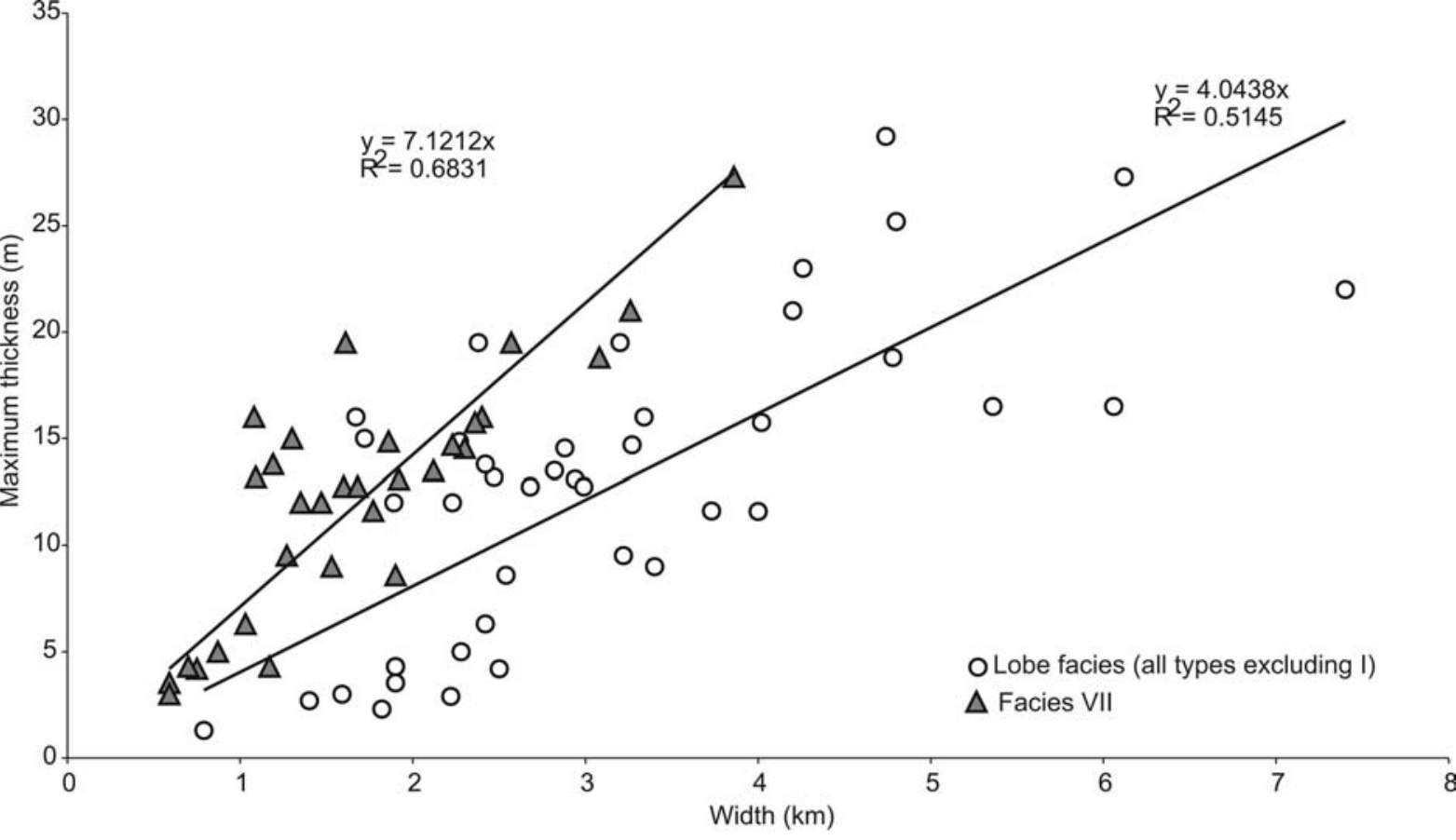




\section{South}

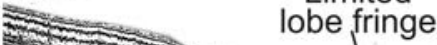

Attenuated penetration

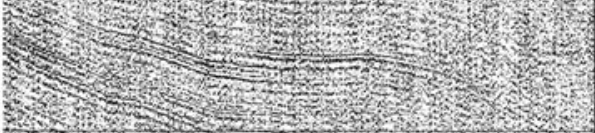

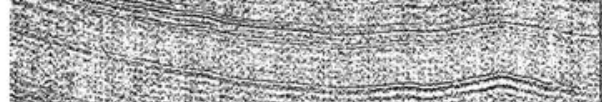

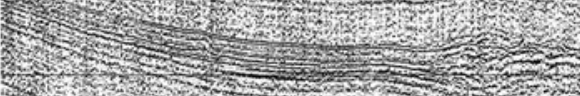

North

sing

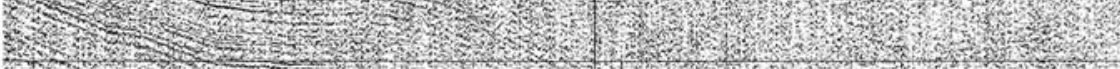

\section{$1 \mathrm{~km}$}

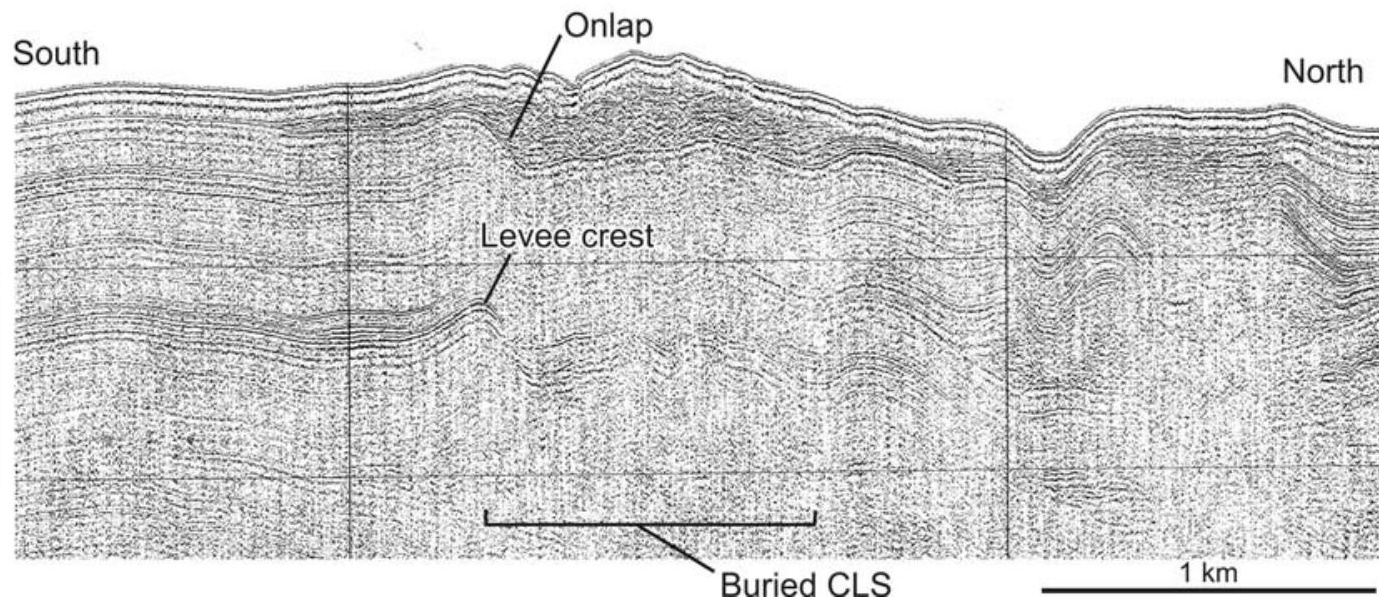


$\cdot 10 \mathrm{~m} \quad 1: 1$ v.e.

C

$110 \mathrm{~m} \quad 5: 1$ v.e.

B
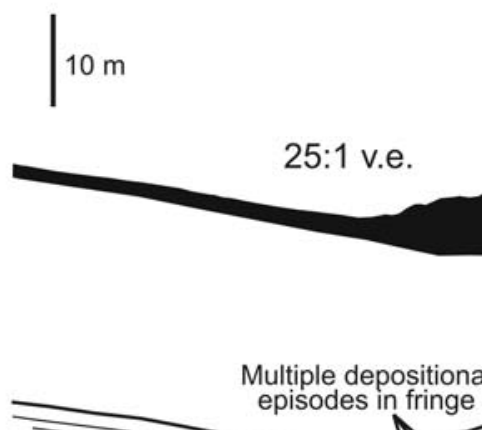

$$
\text { 히 }
$$

A

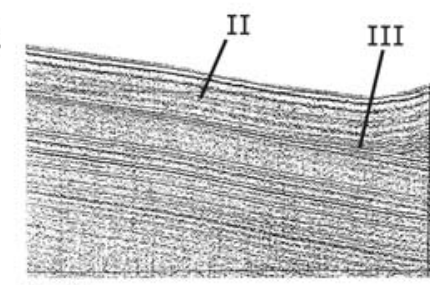

South

North

Figure 13 

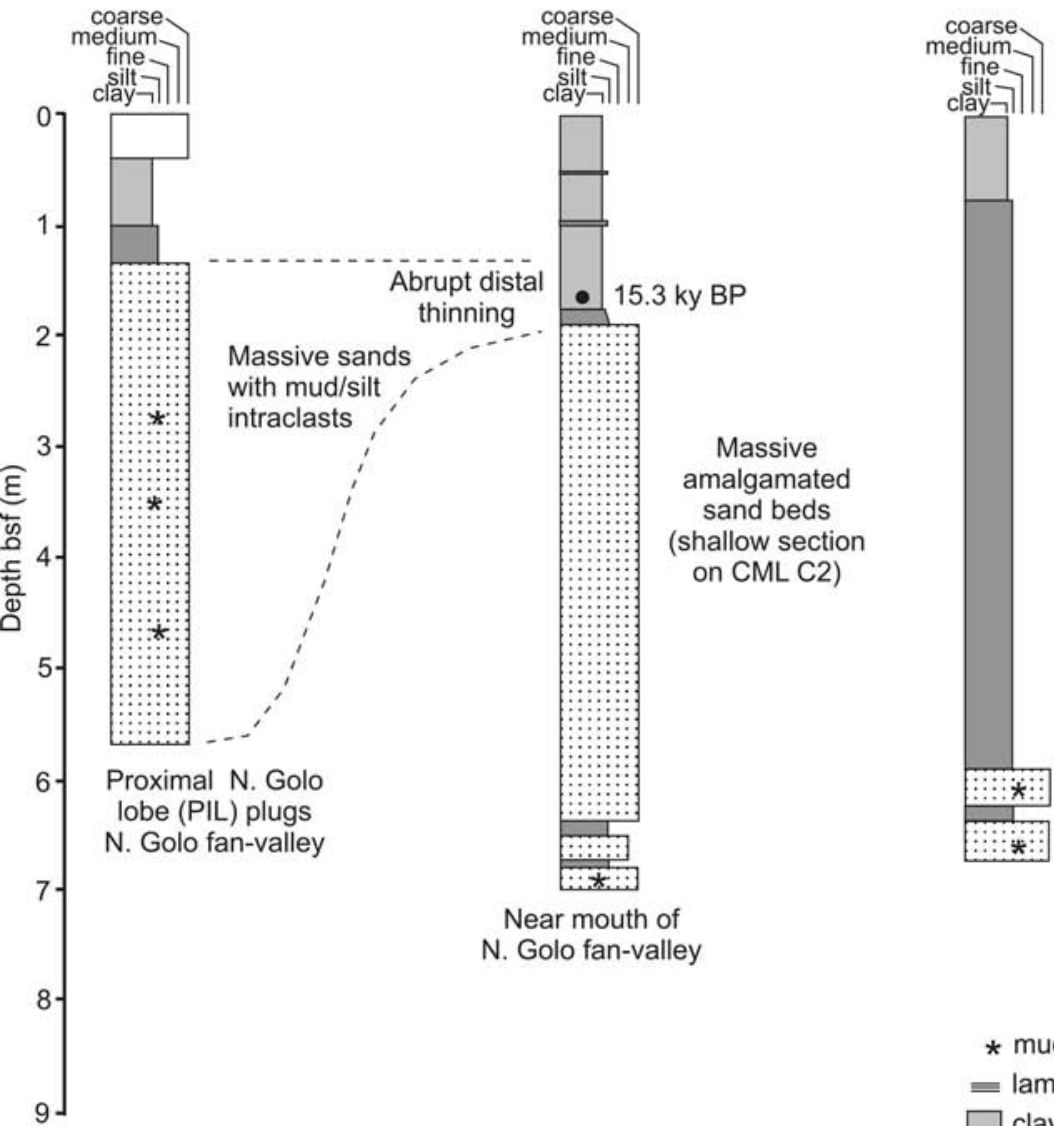

B

PROXIMAL

* mud/silt intraclasts
$\equiv$ laminated sands
$\square$ clay
$\square$ silt
$\square$ sand

Distal fringe of CML C2 (Bouma beds)

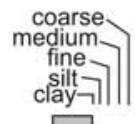

Kco72

.

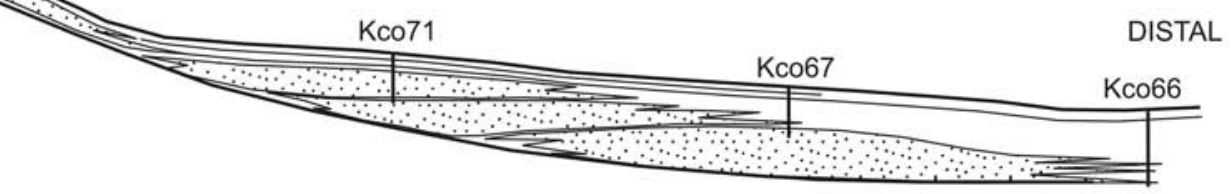

Figure 14 

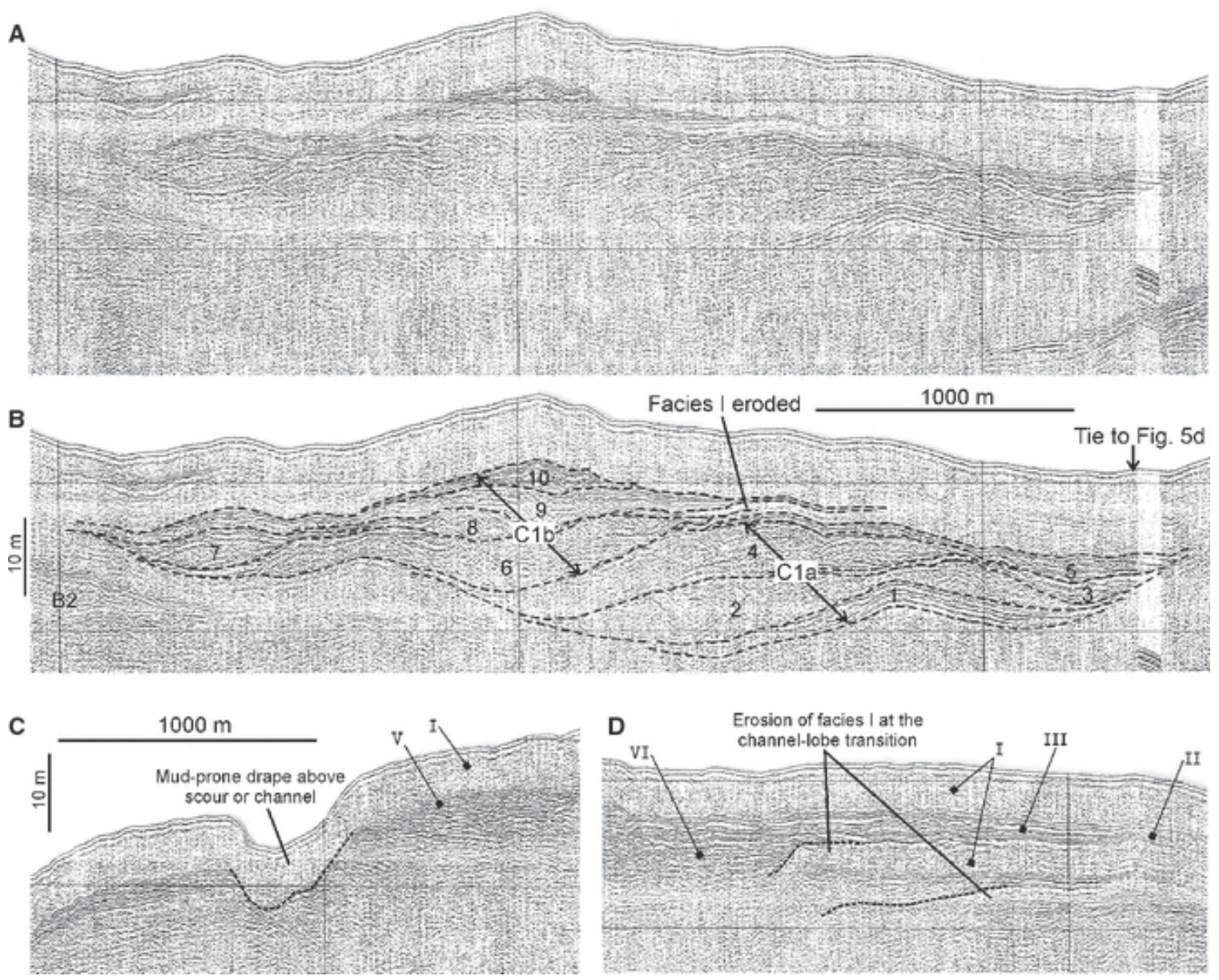

Figure 15 

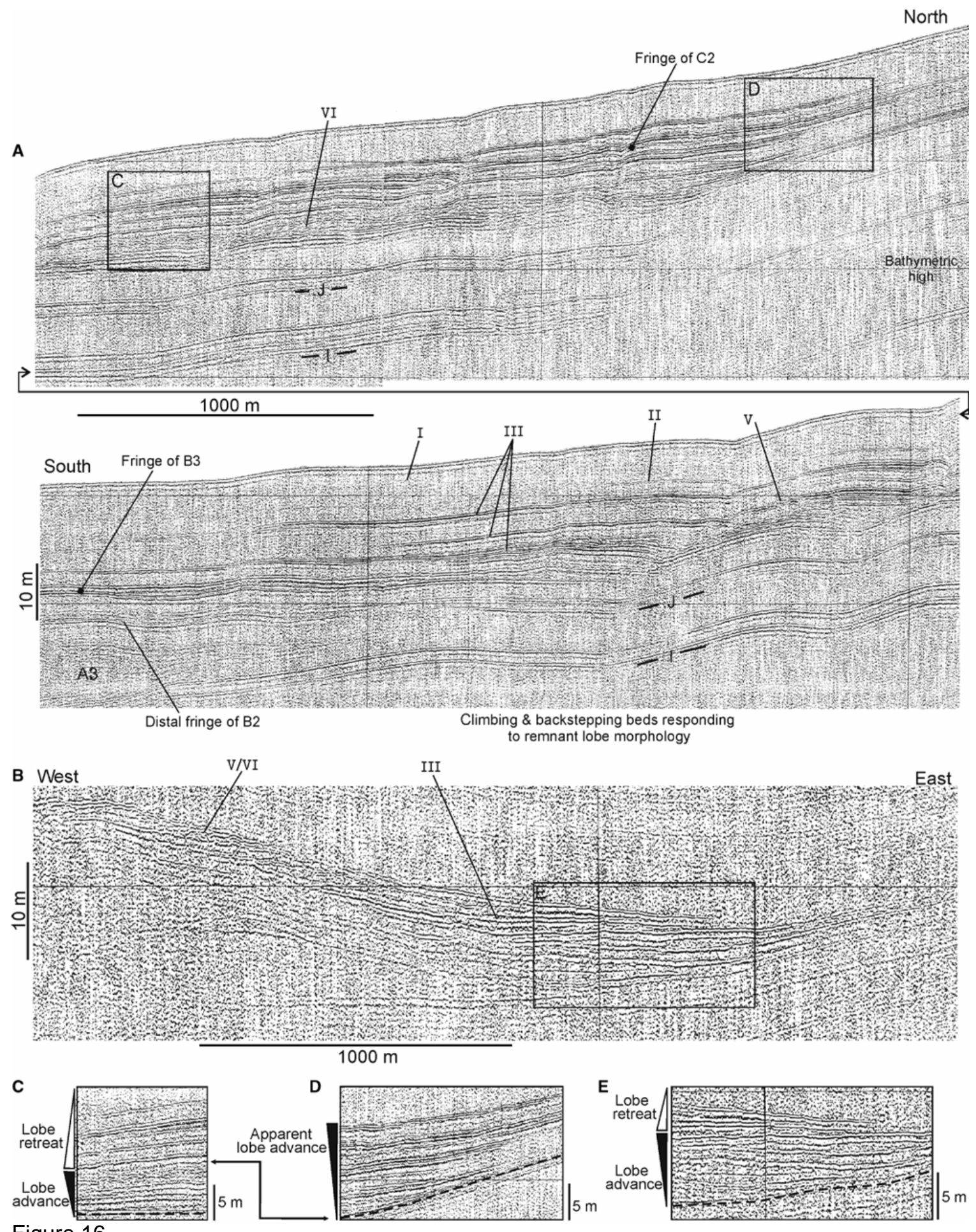

Figure 16 

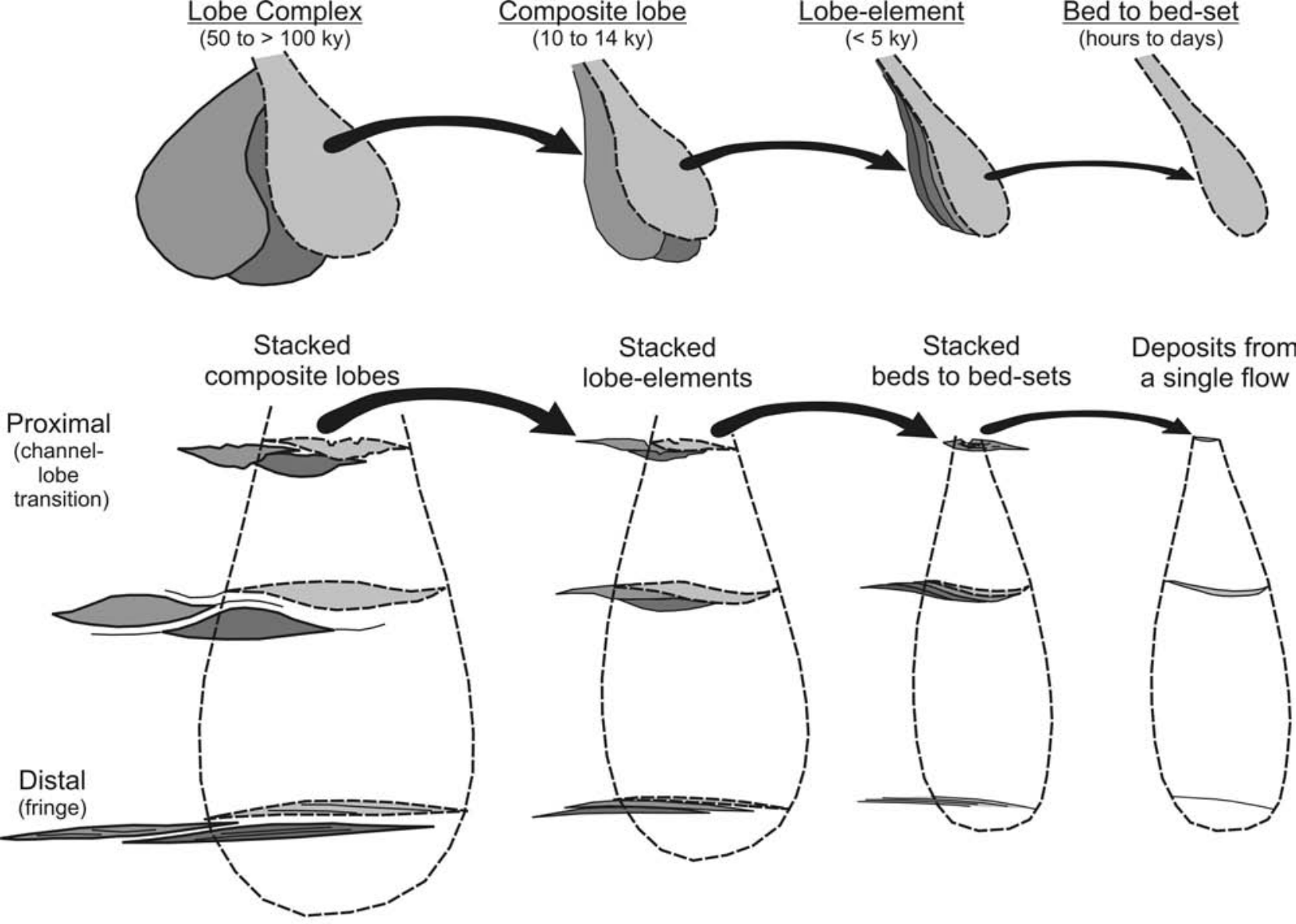


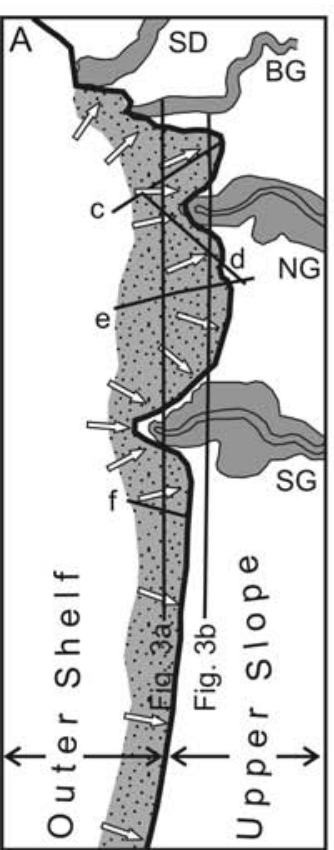

Deltas with 110 m offlap break

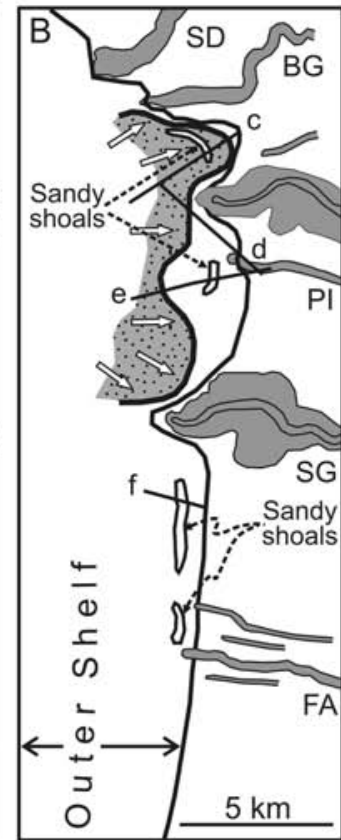

Deltas with $50-80 \mathrm{~m}$ offlap break

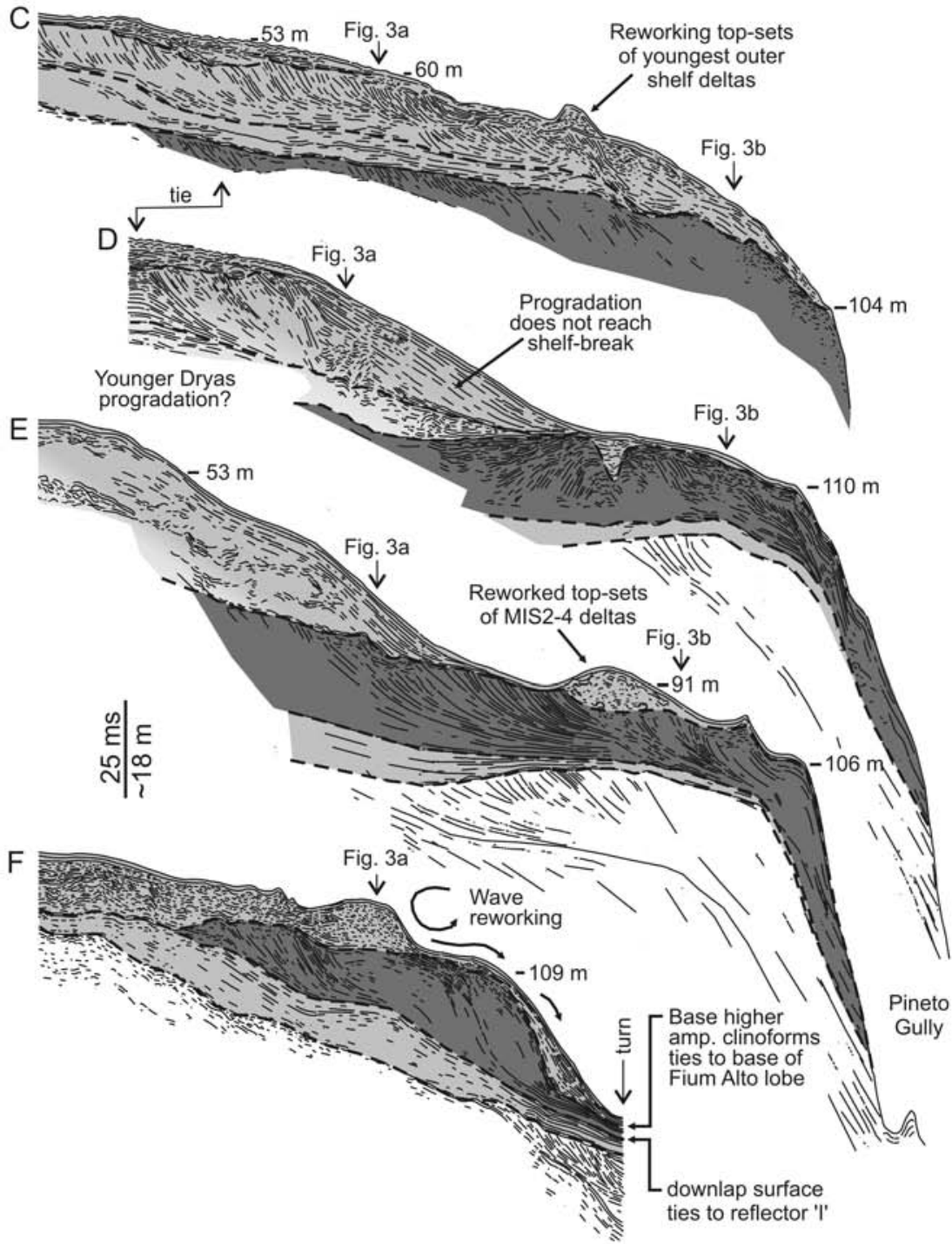

